Article

\title{
Nanoparticles Based on Novel Carbohydrate-Functionalized Polymers
}

\author{
Cláudia D. Raposo ${ }^{+}\left(\mathbb{D}\right.$, Cristiano A. Conceição $^{+}(\mathbb{D}$ and M. Teresa Barros * \\ LAQV-REQUIMTE, Department of Chemistry, NOVA School of Science and Technology, Universidade NOVA \\ de Lisboa, 2829-516 Caparica, Portugal; piccfa@gmail.com (C.D.R.); ca.conceicao@campus.fct.unl.pt (C.A.C.) \\ * Correspondence: mtb@fct.unl.pt; Tel.: +351-212-948-300 \\ + These authors contributed equally to this work, as first authors.
}

Received: 19 March 2020; Accepted: 9 April 2020; Published: 10 April 2020

\begin{abstract}
Polymeric nanoparticles can be used for drug delivery systems in healthcare. For this purpose poly(lactic-co-glycolic acid) (PLGA) and poly(ethylene glycol) (PEG) offer an excellent polymeric matrix. In this work, PLGA and PEG polymers were functionalized with coumarin and carbohydrate moieties such as thymidine, glucose, galactose, and mannose that have high biological specificities. Using a single oil in water emulsion methodology, functionalized PLGA nanoparticles were prepared having a smooth surface and sizes ranging between $114-289 \mathrm{~nm}$, a low polydispersity index and a zeta potential from -28.2 to $-56.0 \mathrm{mV}$. However, for the corresponding PEG derivatives the polymers obtained were produced in the form of films due to the small size of the hydrophobic core.
\end{abstract}

Keywords: PLGA; PEG; polymeric nanoparticles; glucose; galactose; thymidine; mannose; coumarins; drug delivery systems

\section{Introduction}

Described as the manipulation of atomic matter, nanotechnology was described theoretically in the 1960s by Richard Feynman, and the practice emerged a decade later. After Taniguchi's, Drexler's, and other scientist's valuable contributions, nanomedicine has developed [1,2] and recently, the three main applications of nanomedicine are in tissue engineering, nanoprobes, and nanoparticles for drug delivery.

Suitable nanoparticles are capable of transporting drugs in a targeted manner to a specific tissue, cell or organ, minimizing the toxic effects and high therapeutic doses inherent in most current pharmacological treatments [3-5]. Recent advances in drug encapsulation and/or delivery of nanoparticles have demonstrated the enormous potential that these nanomaterials can have in healthcare, and their ability to improve the pharmacokinetic and pharmacodynamic properties of an active ingredient, thereby increasing the effectiveness of treatment and reducing the toxicity to patients [6].

Depending on the application (diagnosis, imaging, or therapy), different types of nanoparticles have been proposed, and these can be divided into two main groups: organic and inorganic nanoparticles. In the first group are dendrimers, liposomes, and polymeric nanoparticles. The second group includes quantum dots, silica, gold, and silver nanoparticles. Due to the high rate of tissue accumulation, that can result in toxicity problems, nanoparticles that cannot be degraded by the body are not as popular and attractive as biodegradable and biocompatible polymeric nanoparticles (PNPs) $[7,8]$.

PNPs play an important role in therapeutic applications, such as encapsulation and controlled drug release [9,10]. The PNP matrix, size [11-13], surface area [14], shape [15,16], and surface electrical 
potential [17-20] are important to circumvent the limitations inherent in drug delivery and must be appropriate for the intended application.

Targeted drug delivery, also known as "magic bullet", is a scientific concept proposed by Paul Ehrlich in 1900, and is the ability to selectively eliminate pathogenic microorganisms without harming the patient themselves, intending that the drug only acts on its intended target. Unlike most currently available treatments, PNPs capable of targeting drug delivery to a particular tissue, cell or organ can be achieved if the surface of the PNP is functionalized accordingly (derivatization with antibodies or their modified fragments, proteins, peptides, oligonucleotides, or carbohydrates) [19-21]. Highly specific interactions occur between these ligands and certain receptors of different cell types. Lectins, for example, present in different organs such as liver cells or over-expressed on the membrane surface of cancer cells, are able to specifically internalize monosaccharide molecules such as lactose, glucose, galactose, mannose, amongst others, suggesting the ability to target or accumulate PNPs in these types of lectin-containing cells [21,22].

With all of this in mind, we have attempted to functionalize commercial polymers, namely poly(ethylene glycol) (PEG) and poly(lactic-co-glycolic acid) (PLGA), in order to obtain drug delivery agents, either pro-drugs or nanoparticles for drug encapsulation. Monosaccharides (glucose, galactose, mannose, and thymidine) were bonded to these polymers to allow specific interactions between cell receptors and drug delivery agents. Coumarins were also included to potentially increase the pharmaceutical activity of these polymers, since they are known for their biological properties [23-26], but also to exploit their use as traceable probes due to their fluorescence character. In some cases, the click chemistry methodology [27] was used to establish the covalent bonds between these building blocks. More information about the formation of triazole rings with polymers can be read in an extensive review written by Arslan and co-workers [28], and in a complete review of polymeric scaffolds for tissue engineering, written by Zou and co-workers [29].

\section{Results and Discussion}

Our synthetic strategy began with the preparation of ligands that would be bonded to poly(ethylene glycol) (PEG) and poly(lactic-co-glycolic acid) (PLGA) polymers. We wanted these bonds to be strong, but also easily formed, and both 1,2,3-triazole ring and amide linkages present those features, whereby coumarins, carbohydrates and the polymers were modified accordingly, as described below.

\subsection{Ligand Synthesis and Preparation-Coumarins}

Coumarins can be obtained commercially or synthesized either by Pechmann condensation [30], Knoevenagel condensation [31], Perkin reaction [32], or Reformatsky reaction [33], the first two methods being the most widely used. For this work, however, only one coumarin was synthesized. Pechmann reaction between 2-methylresorcinol and diethyl-2-acetylglutarate in acidic media afforded 1 in $60 \%$ yield (Scheme 1).

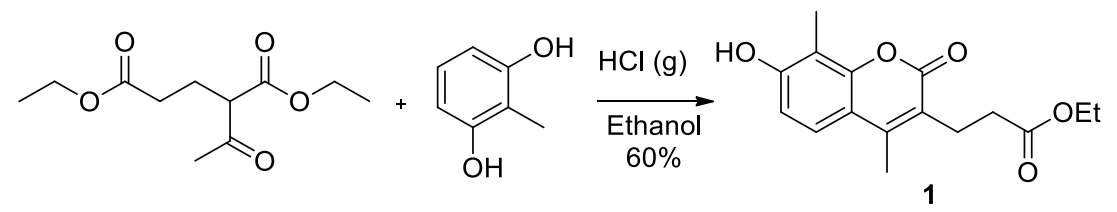

Scheme 1. Pechmman condensation between 2-methylresorcinol and diethyl-2-acetylglutarate affording coumarin 1.

Propargylation reactions of $\mathbf{1}$, and other commercially available coumarins, namely umbelliferone, 3-carboxylic acid coumarin, and 4-methyl-7-hydroxy coumarin, are presented in Scheme 2. The propargylation conditions used were the ones already reported in the literature $[34,35]$. Alkyne coumarins 2, 4, 5, and 6 were obtained in excellent yields, and pure enough for further reactions. 
NMR and FT-IR spectra (see Supplementary Materials for ${ }^{1} \mathrm{H},{ }^{13} \mathrm{C}$ and MS/MALDI-TOF spectra for novel synthesized compounds) were in accordance with those already reported in the literature. For propargylated coumarin 4, methylene protons were observed at $4.77 \mathrm{ppm}$, and the alkyne proton at $2.58 \mathrm{ppm}$. Alkyne stretch bands were observed at 3266 and $2119 \mathrm{~cm}^{-1}$. Coumarin 5 presented the methylene proton signal at $4.95 \mathrm{ppm}$ and the alkyne proton at $2.56 \mathrm{ppm}$. FT-IR spectrum presented the alkyne stretches at 3315 and $2117 \mathrm{~cm}^{-1}$. Ester hydrolysis of 2 was accomplished with sodium hydroxide in ethanol at $80{ }^{\circ} \mathrm{C}$, affording 3 in $95 \%$ yield.<smiles></smiles>

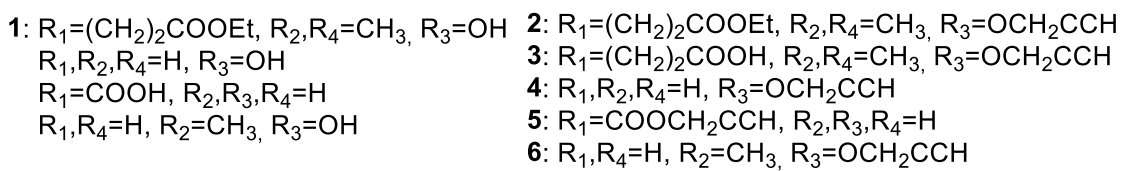

2 to 3 : ester hydrolysis

Scheme 2. Propargylation of 1, umbelliferone, 3-carboxylic acid, and 4-methyl-7-hydroxy coumarin, affording the corresponding alkynes. Reaction conditions for ester formation: i) propargyl alcohol, $\mathrm{N}, \mathrm{N}$-dicyclohexylcarbodiimide (DCC), 4-dimethylaminepyridine (DMAP), $\mathrm{CH}_{2} \mathrm{Cl}_{2}$ (DCM), $18 \mathrm{~h}$. Conditions for ether formation, and ii) propargyl bromide, $\mathrm{KI}, \mathrm{K}_{2} \mathrm{CO}_{3}$, dimethylformamide (DMF), $80^{\circ} \mathrm{C}, 2 \mathrm{~h} 30 \mathrm{~min}$.

In some cases, a linker was necessary in order to bond the coumarin, or the carbohydrate, moiety to the polymer and for these cases compound 7 was prepared. Due to its high volatility and reactivity, 7 was always maintained in diethyl ether, even for its quantification and characterization. Subsequent triazole ring formation with coumarin 6, afforded 8 in good yield (Scheme 3).

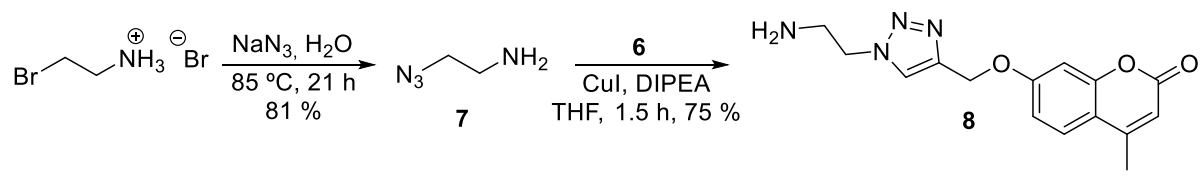

Scheme 3. Triazole linker 8 was prepared by the substitution of bromide in 2-bromoethylamine hydrobromide using sodium azide, followed by cycloaddition to form the 1,2,3-triazole ring.

\subsection{Ligand Preparations-Carbohydrates}

Specific carbohydrate derivatization was challenging due to the presence of several hydroxyl groups having similar reactivities. However, depending on the reaction conditions, the anomeric hydroxyl can be preferential replaced. Furthermore, in order for a carbohydrate to be recognized by lectins, it often must be non-reducing.

Insertion of a triazole ring between the carbohydrate moiety and the coumarin/polymer moieties not only increases the linkage strength, but mimics the amide group, which can induce, or improve, the biological activity of the final compounds. Propargylation of glucose, galactose, and mannose (Scheme 4) using immobilized sulfuric acid on silica [36], afforded the necessary terminal alkynes, 9-11, for posterior cycloaddition reactions. The propargylation yields obtained were poor to moderate $(38 \%-68 \%)$, and the products were mixtures of $\alpha$ and $\beta$ anomers, with a 2:1 ratio. This ratio was calculated taking advantage of the vicinal coupling constants characteristics for hexoses ( $\alpha$ proton near 5 ppm as a broad singlet and $\beta$ proton around $4.50 \mathrm{ppm}$, with ${ }^{3} J_{\mathrm{H} 1-\mathrm{H} 2}=7.9 \mathrm{~Hz}$ ), and with ${ }^{1} J_{\mathrm{H}-\mathrm{C}}$ coupling constant for mannopyranose 11. Benzylation of $\alpha$ and $\beta$ propargyl glucopyranosyl mixtures afforded the per-O-benzylated anomers, which could be separated by column chromatography, using 6:1 hexane/ethyl acetate as eluent. 


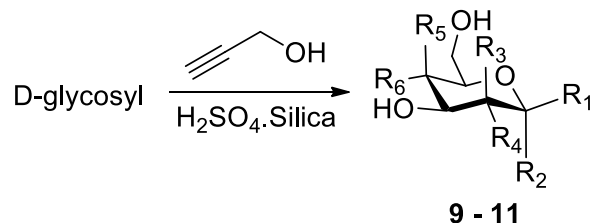

$$
\begin{aligned}
\text { 9: } \mathrm{R}_{1}, \mathrm{R}_{2}=\mathrm{H} \text { or } \mathrm{OCH}_{2} C C H, \mathrm{R}_{4}, \mathrm{R}_{6}=\mathrm{OH}, \mathrm{R}_{3}, \mathrm{R}_{5}=\mathrm{H} \\
\text { 10: } \mathrm{R}_{1}, \mathrm{R}_{2}=\mathrm{H} \text { or } \mathrm{OCH}_{2} C C H, \mathrm{R}_{4}, \mathrm{R}_{5}=\mathrm{OH}, \mathrm{R}_{3}, \mathrm{R}_{6}=\mathrm{H} \\
\text { 11: } \mathrm{R}_{1}, \mathrm{R}_{2}=\mathrm{H} \text { or } \mathrm{OCH}_{2} \mathrm{CCH}, \mathrm{R}_{3}, \mathrm{R}_{6}=\mathrm{OH}, \mathrm{R}_{4,} \mathrm{R}_{5}=\mathrm{H}
\end{aligned}
$$

Scheme 4. Propargylation reaction of D-glucose, D-galactose, and D-mannose using sulfuric acid immobilized on silica, affording the alkynes $\mathbf{9}, \mathbf{1 0}$, and $\mathbf{1 1}$, respectively.

Acetylation of propargyl glucopyranose 9, afforded 12. Subsequent triazole formation with azide 7 afforded 13 in good yield. De-acetylation using sodium methoxide led to the corresponding product 14 (Scheme 5).

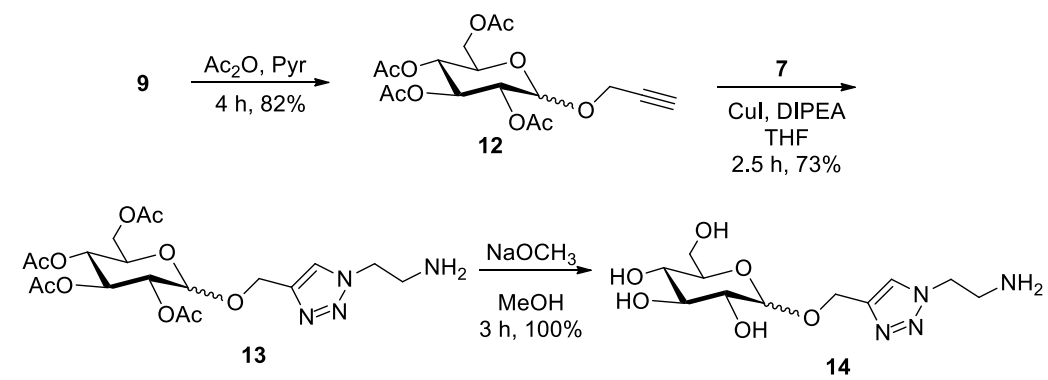

Scheme 5. Preparation of glycosyl amine 14 from propargyl glucoside $\mathbf{9}$.

\subsection{Ligand Preparations-Thymidine}

Tosylation of the primary hydroxyl group of 2'-deoxythymidine was accomplished using tosyl chloride (15, Scheme 6). Subsequent reaction with sodium azide, either by conventional heating in dimethylformamide (DMF) using an oil bath $\left(85^{\circ} \mathrm{C}, 15 \mathrm{~h}, 87 \%\right)$, or using microwave irradiation $\left(100^{\circ} \mathrm{C}\right.$, $250 \mathrm{~W}, 2 \mathrm{~min}, 90 \%$ ), afforded the corresponding azide 16. Although a yield improvement was not significant using microwave heating, the reaction time was drastically reduced.

Having the ligands already prepared, they were used to prepare PEG and PLGA derivatives, as described in the following sections.

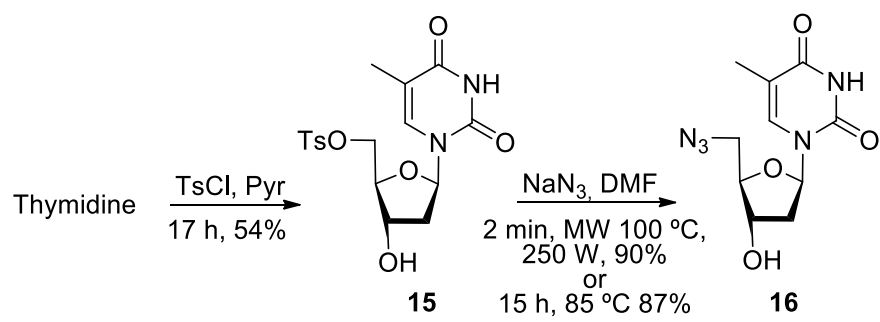

Scheme 6 . Synthesis of thymidine azide 16 by regioselective tosylation, followed by azide substitution, either using microwave or conventional heating.

\subsection{PEG Derivatives}

PEG is a versatile polymer for pro-drug development due to its high solubility in water and available commercially at various molecular weights, and its stealth properties [37]. PEG pro-drugs often diminish collateral effects and can be specifically administered on targeted tissues [38]. Although the conjugation of pharmaceutical agents with PEG has brought significant improvements such as an increased solubility in water, prolonged liberation rates, and reduction of toxicity, problems such as 
the necessity for high doses and drug resistance are still awaiting resolution. Multi-therapy presents itself as a viable solution since polymeric pro-drugs are able to form nanoparticles that are able to encapsulate a different drug, allowing the reduction of administered doses, and consequently an increased therapeutic efficiency [39-41].

Esterification of coumarin 3-carboxylic acid with PEG using N,N-dicyclohexylcarbodiimide (DCC), and catalytic 4-dimethylaminepyridine (DMAP, Scheme 7) afforded the fluorescent polymer 17 in excellent yield. Product formation was observed by FT-IR, which confirmed the presence of the ester linkage at $1766 \mathrm{~cm}^{-1}$. The proton NMR spectrum showed the presence of one coumarin moiety, determined by comparing the relative intensity of the coumarin signals to PEG signals, since PEG with an average molecular weight of $1000 \mathrm{~g} / \mathrm{mol}$ was expected to present between 84 and 96 protons. Integration of aromatic signals between 8.57 and 7.32 ppm for one coumarin, resulted in 88 PEG protons (between 4.60 and $3.50 \mathrm{ppm}$ ), which is within the expected values. This is a very important result, since the other PEG hydroxyl should be free to link to the carbohydrate moiety. ${ }^{13} \mathrm{C} \mathrm{NMR}$ spectrum supports the esterification success through coumarin signals between 117 and 163 ppm. The terminal hydroxyl of ester 17 was then tosylated to provide ester 18, in good yield. A tolyl methyl proton signal was observed at $2.45 \mathrm{ppm}$ and a corresponding carbon signal at $21.6 \mathrm{ppm}$. Aromatic proton signals where observed between 7.90 and 7.32 ppm, and between 136.5 and 115.5 ppm in the carbon spectrum. The tosyl group was substituted using sodium azide in DMF, affording the azide 19 in very good yield. Product formation was confirmed by the absence of tosyl signals both in the proton and carbon spectra, and by the observation of an azide stretch band in the FT-IR at $2104 \mathrm{~cm}^{-1}$. Cycloaddition with the previously prepared propargyl galactopyranose 10 using catalytic $\mathrm{CuI}$, and diisopropylethylamine (DIPEA) in freshly distilled tetrahydrofuran (THF) afforded the desired triazole-containing glycoconjugate 20 in only $18 \%$ yield. The poor yield obtained is believed to be due to copper complexation with the free hydroxyls of propargyl galactopyranose. Adding 2,2'-bipyridyl in excess to the reaction mixture, did not improve this result [42]. A Proton NMR spectrum showed the triazole proton signals shifted between 8.23 and 7.99 ppm, and the coumarin signals in the expected aromatic region, namely between 8.60 and 7.30 ppm. Galactopyranose signals were observed between 5.10 and 4.40 ppm, with PEG signals between 4.30 and 3.34 ppm. Carbon spectrum confirmed these results, mainly by the presence of the anomeric carbon at 98.8 ppm and triazole signal at $124.9 \mathrm{ppm}$. Matrix-Assisted Laser Desorption/Ionization with Time-of-Flight analyser (MALDI-TOF) mass spectrum presented a medium mass/charge of 1512, where the expected value was $1401 \mathrm{~m} / \mathrm{z}$., which result is within the range for $\left(\mathrm{C}_{2} \mathrm{H}_{4} \mathrm{O}\right)_{\mathrm{n}} \mathrm{H}_{2} \mathrm{O}$, with $\mathrm{n}=21-24$.

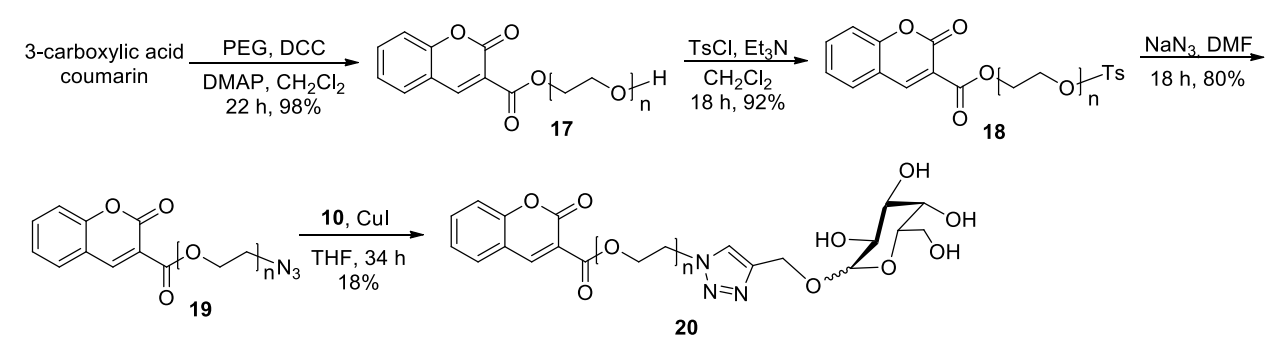

Scheme 7. Synthesis of glycoconjugate 20.

In order to form symmetric or asymmetric PEG derivatives diazide 22 was prepared through the sodium azide reaction with ditosylate 21 (Scheme 8). Formation of di-tosylated product 21 was confirmed by proton NMR, where the relative intensity of the tosyl signals, compared to the PEG methylene signals, were as expected for the di-tosylation. As such, eight protons appear between 7.90 and 7.30 ppm corresponding to both tosyl groups. The two corresponding methyl protons presented as a singlet at $2.45 \mathrm{ppm}$. Compound 22 was confirmed by the absence of tosyl NMR signals, and the presence of a triplet at $3.39 \mathrm{ppm}$, corresponding to both methylene groups bonded to azide groups. 


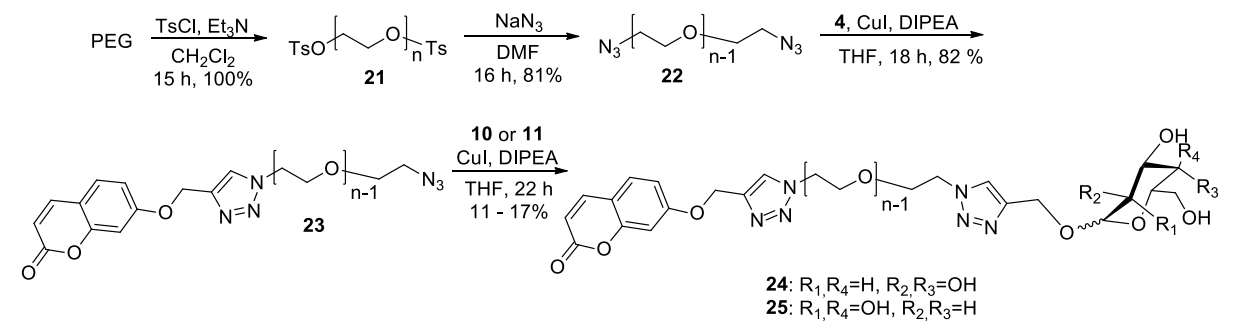

Scheme 8. Synthesis of glycoconjugates 24 and 25 from poly(ethylene glycol) (PEG).

Equimolar cycloaddition of $\mathbf{2 2}$ with previously prepared propargyl coumarin $\mathbf{4}$ afforded $\mathbf{2 3}$ with very good yields. Proton spectrum presented in the aromatic region the protons belonging to the coumarin (between 7.70 and $6.20 \mathrm{ppm})$ and the triazole $(8.00 \mathrm{ppm})$ moieties. The methylene of the coumarin moiety was observed at $5.29 \mathrm{ppm}$ as a singlet, as expected. PEG proton signals were shifted in four different places, where the most deshielded triplet, at $4.60 \mathrm{ppm}$, corresponded to the methylene bonded to the triazole moiety, and the more shielded one, at $3.39 \mathrm{ppm}$ corresponded to the methylene bonded to the azide moiety. Carbon spectrum sustained these results. FT-IR spectrum showed the azide band at $2106 \mathrm{~cm}^{-1}$, indicating that unwanted di-cycloaddition was not obtained.

Subsequent cycloaddition on the other side of the polymer, either using propargylated galactopyranose $\mathbf{1 0}$ or propargylated mannopyranose 11, led to the formation of glycoconjugates $\mathbf{2 4}$ or 25 , respectively, in $11 \%$ and $17 \%$ yields. Structure confirmation by proton NMR was difficult due to the overlap of PEG and carbohydrate signals, while MALDI results were in accordance with the expected estimated values (estimated medium value of $1426 \mathrm{~m} / \mathrm{z}$, obtained $1511 \mathrm{~m} / \mathrm{z}$ for compound 24, and 1477 $\mathrm{m} / \mathrm{z}$ for compound 25).

Diesterification of PEG with coumarin alkyne 3 using DCC afforded a new fluorescent polymer, 26 (Scheme 9). Product $\mathbf{2 6}$ was easily identified by proton NMR, where the relative intensity of coumarin signals, compared to PEG methylene signals, were as expected for the diester. As such, 4 aromatic protons at 7.47 and $6.98 \mathrm{ppm}$ corresponded to both coumarins. PEG proton signals were identified at 4.23 and $3.66 \mathrm{ppm}$, with a relative intensity for 86 protons. Carbon spectrum analysis was also consistent with the proposed structure (see experimental part).

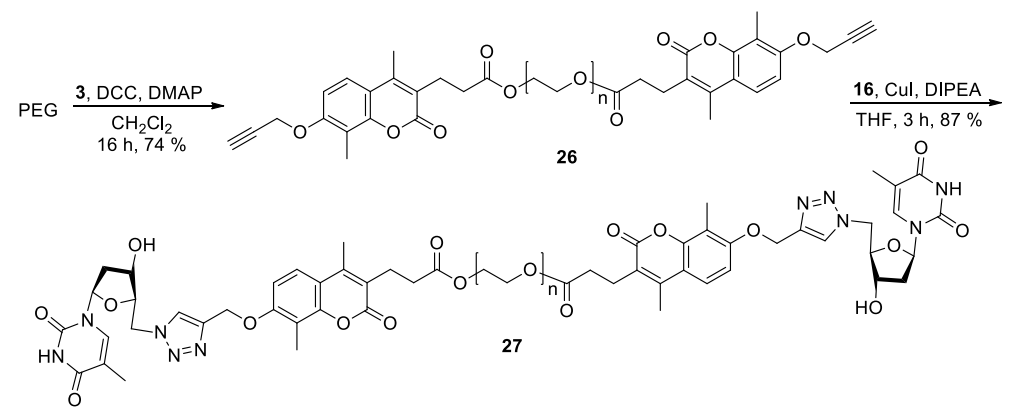

Scheme 9. Synthesis of a double thymidine-containing fluorescent PEG derivative, 27, starting by PEG di-esterification with coumarin 3 , followed by double triazole ring formation with thymidine derivative 16.

Subsequent double azide-alkyne Huisgen cycloaddition with thymidine azide $\mathbf{1 6}$ using a catalytic amount of $\mathrm{CuI}$ and DIPEA in THF, afforded the symmetric polymer 27. Structural characterization was observed to be in agreement with the proposed structure. More precisely, proton NMR spectrum showed new triazole protons at $7.77 \mathrm{ppm}$ and coumarin signals in the expected aromatic region at 7.41 and $6.98 \mathrm{ppm}$. Thymidine signals were observed at 7.30, 6.24, and $4.47 \mathrm{ppm}$, and PEG signals at 4.20 and $3.60 \mathrm{ppm}$. All the relative intensity for the assigned protons were in agreement with bis-thymidine cycloaddition. The carbon spectrum confirmed these results, mainly by the presence of a triazole signal at $135.5 \mathrm{ppm}$, the anomeric carbon at $84.9 \mathrm{ppm}$ and the PEG main carbon chain at $70.5 \mathrm{ppm}$. 
The MALDI-TOF expected medium value was $2132 \mathrm{~m} / \mathrm{z}$, and it was obtained $2153 \mathrm{~m} / \mathrm{z}$ for compound 27, with sizes ranging from 1932 to $2461 \mathrm{~m} / \mathrm{z}$, in which the increment observed was due to ethylene glycol monomer.

\subsection{PLGA Derivatives}

PLGA is a hydrophobic, linear and biocompatible polymer, approved by the FDA and EMA for biological applications [43]. Upon hydrolysis, PLGA is able to release pharmaceutical agents, and the resulting lactic and glycolic acids are metabolized on the Krebs cycle [44]. A polymer with a molecular weight range between 7000 and 17,000 g/mol was chosen with a 50:50 glycolic/lactic acid ratio, which translates into a more amorphous final structure.

PLGA glycoconjugate 28 was prepared by amide formation between 14 and PLGA using methanesulfonic acid (Scheme 10). Due to the fact that amines are more reactive than alcohols, it was assumed that an amide was the major product of this reaction, although esterification may have also occurred.

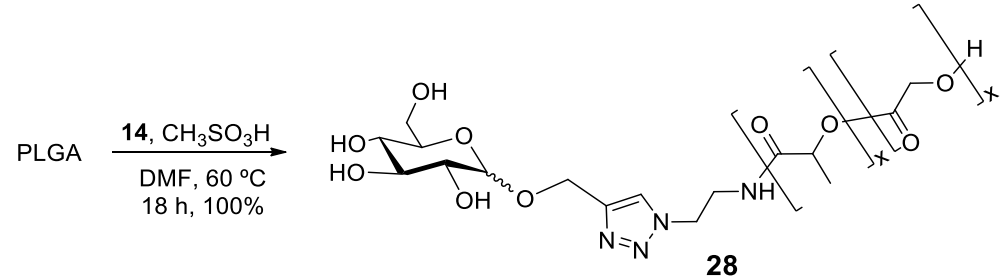

Scheme 10. Amidation reaction between poly(lactic-co-glycolic acid) (PLGA) and previously prepared glycoside 14 to afford the PLGA glycoconjugate 28.

Coumarin 8 reacted with PLGA in the presence of methanesulfonic acid (Scheme 11) to afford the fluorescent amide, 29.

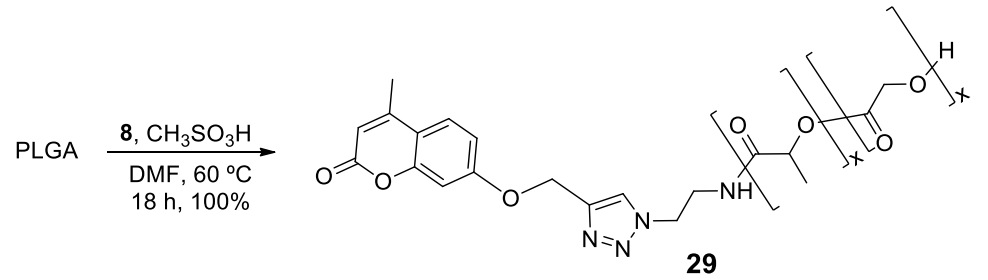

Scheme 11. Synthesis of fluorescent PLGA derivative, 29 by direct PLGA amidation with coumarin 8 in acidic conditions.

Proton NMR analysis of compound 28 identified the methyl, methylene, and methine groups that form the polymer at 1.58, 4.83, and $5.22 \mathrm{ppm}$, respectively. The characteristic signal from the triazole moiety can be identified at $7.01 \mathrm{ppm}$, and a few sugar signals between 4.43 and $4.11 \mathrm{ppm}$. For polymer 29 it was also possible to identify the methyl, methylene, and methine groups from the polymer chain at $1.58,4.83$, and $5.24 \mathrm{ppm}$, respectively, plus the coumarin and triazole characteristic protons at $8.29,7.80$, and $7.54 \mathrm{ppm}$. Identification of these ligands was very difficult, due to high NMR signal accumulation from the polymer structure. Nevertheless, it was possible to identify very distinctive signals for both polymers. MALDI-TOF analysis could not be made for these polymers due to their very high polydispersity. Correlation between zeta potentials of their respective nanoparticles, and these observed NMR signals allowed us to conclude that the functionalization had occurred.

\subsection{Nanoparticles Preparation and Characterization}

Polymeric glycoconjugates were transformed into nanoparticles with the glycosides towards their exterior. Oil in water emulsification/solvent evaporation technique is an easy and highly reproducible method for nanoparticle preparation, and it was our choice for the transformation of the prepared polymers into nanoparticles. 
Nanoparticles from glycoconjugate 20 were prepared and analyzed by Scanning Electron Microscopy (SEM) and the results are presented in Figure 1A,B. This glycoconjugate formed mostly a polymeric film upon deposition, with some dispersed agglomerates. The size of the agglomerates ranged between 220 and $580 \mathrm{~nm}$.
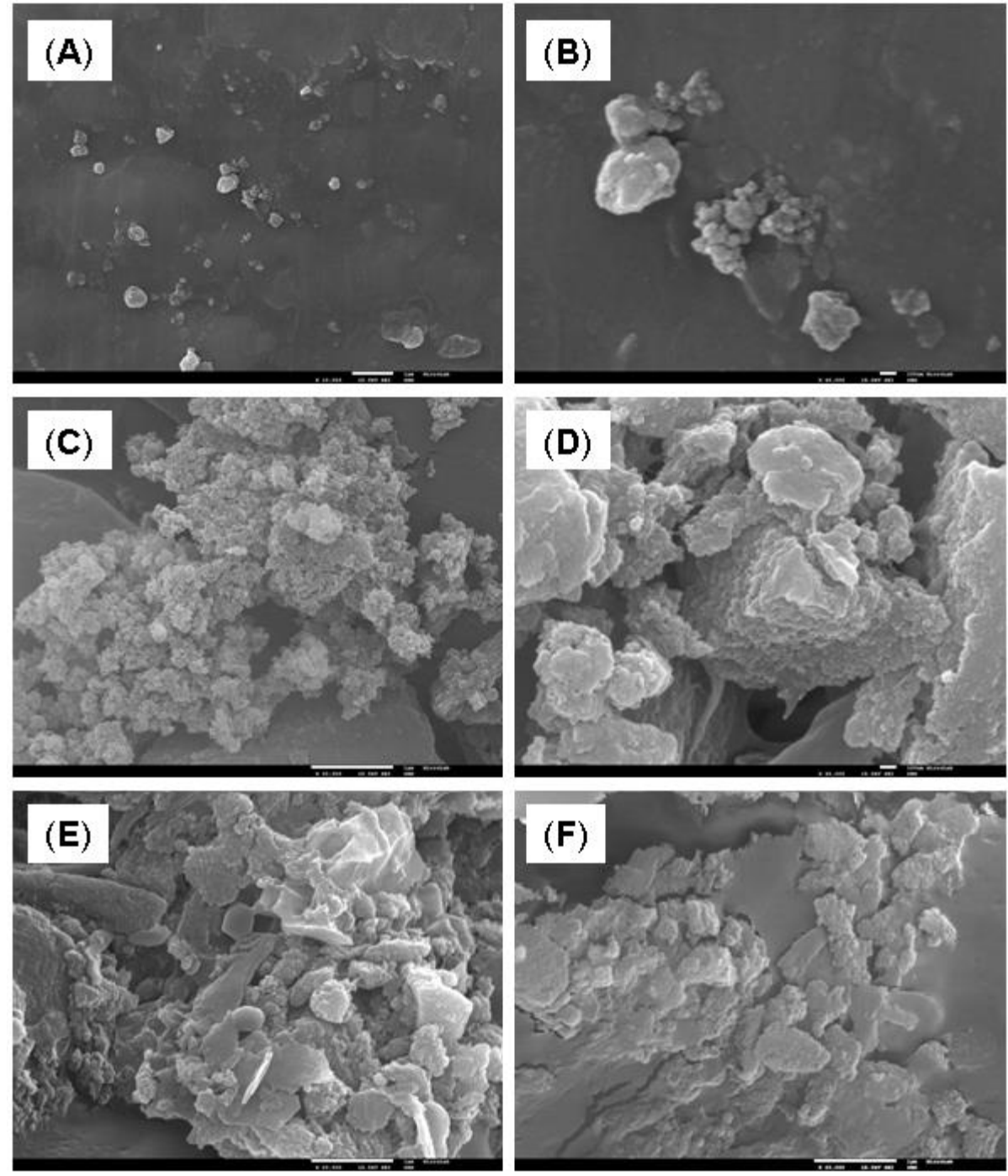

Figure 1. Scanning Electron Microscopy (SEM) micrographs of PEG derivatives after oil-in-water emulsification method to form nanoparticles. (A,B) correspond to galactoconjugate 20; (C,D) correspond to galactoconjugate 24; and (E,F) account for mannoconjugate 25. Left images have a magnification of 20,000 times, with the bar corresponding to $1 \mu \mathrm{m}$, with the exception of $(\mathbf{A})$, where magnification is 10,000 times. Right images have a magnification of 40,000 times, with the bar corresponding to $100 \mathrm{~nm}$.

Glycoconjugates 24 and 25 were also transformed into nanoparticles and analyzed by SEM, and are presented in Figure 1C-F. Galactoconjugate $\mathbf{2 4}$ formed more agglomerates than glycoconjugate 20, and a film was still present. For the mannoconjugate 25, it was observed that it formed irregular films, with multiple cracks, and a high degree of convolution of neighboring agglomerates either by the polymer's preferential formation of films, or due to film deposition on top of those agglomerates. Dynamic Light Scattering (DLS) technique (results presented in Figure 2), where the particles are suspended in water in a colloidal manner, showed average particle size of 253 (20), 118 (24), and $193 \mathrm{~nm}$ (25), peak size of 219 (20), 105 (24), and $171 \mathrm{~nm}$ (25) and high polydispersity indexes of 5.828 (20), 0.440 (24), and 0.682 (25). These results confirmed that PEG derivatives formed polydisperse samples, with aggregates. 
(A)

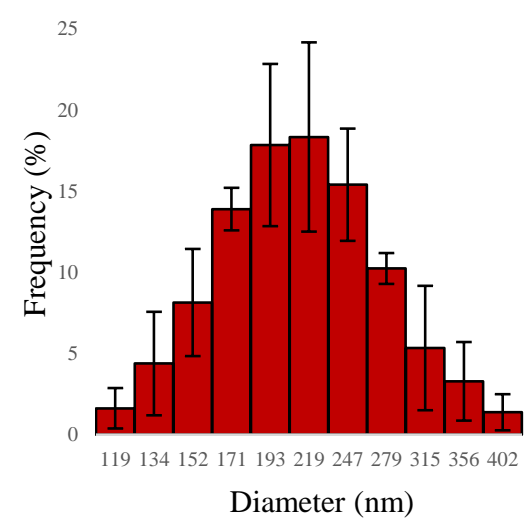

(B)

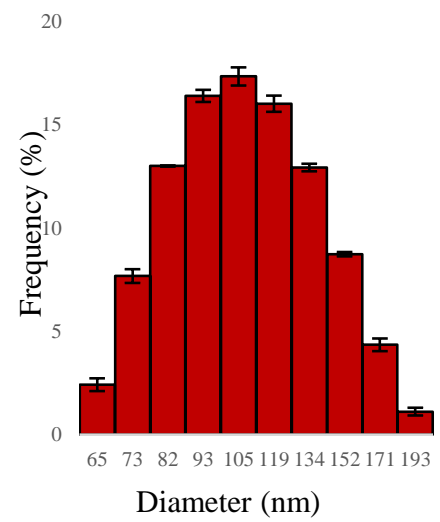

(C)

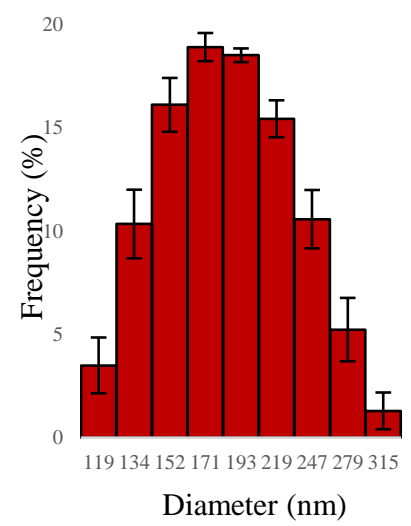

Figure 2. Size profiles of nanoparticles from PEG derivatives, measured by DLS. (A) Galactoconjugate 20. (B) Galactoconjugate 24. (C) Mannoconjugate 25.

PLGA glucoconjugate $\mathbf{2 8}$ was capable of forming spherical nanoparticles, with a smooth surface and with practically no aggregation as seen in Figure 3A,B. The particles presented a size range of 114-234 nm. DLS gave similar results, with an average particle size of $189 \mathrm{~nm}$, peak size $171 \mathrm{~nm}$ (Figure 4A) and a low polydispersity index of 0.174 . The zeta potential was also measured, with a value corresponding to $-28.2 \mathrm{mV}$.
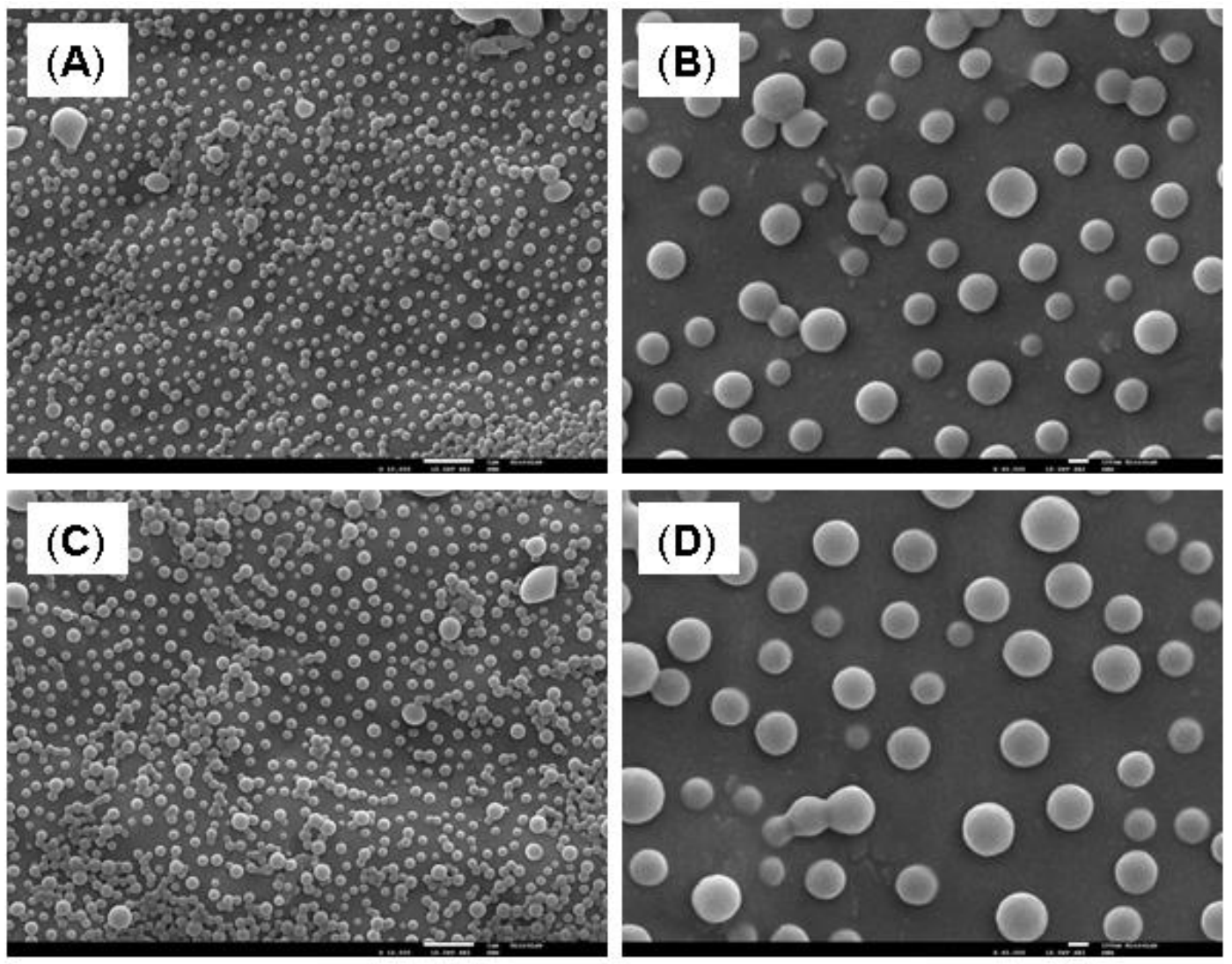

Figure 3. SEM micrographs of PLGA derivatives after oil-in-water emulsification method to form nanoparticles. (A,B) correspond to glucoconjugate 28 and $(\mathbf{C}, \mathbf{D})$ correspond to coumarin-containing PLGA derivative 29. Left images have a magnification of 10,000 times, with the bar corresponding to $1 \mu \mathrm{m}$. Right images have a magnification of 40,000 times, with the bar corresponding to $100 \mathrm{~nm}$. 

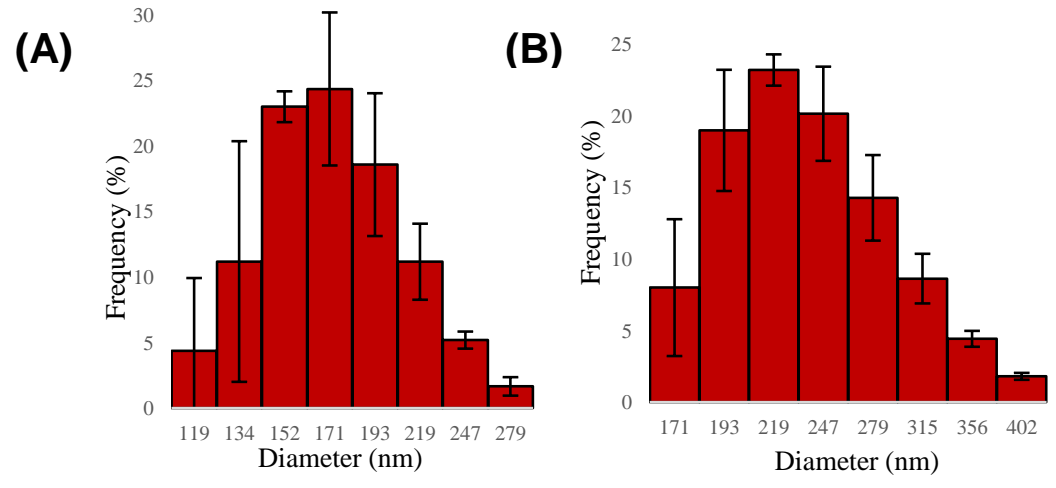

Figure 4. Size profiles of nanoparticles from PLGA derivatives, measured by DLS. (A) Glucoconjugate 28. (B) Coumarin-containing derivative 29.

Nanoparticles from the coumarin-containing PLGA derivative, 29, presented a spherical and smooth surface, with no aggregation (Figure 3C,D) and size range of 174-289 nm. DLS results showed an average particle size of $273 \mathrm{~nm}$, peak size $219 \mathrm{~nm}$ (Figure 4B), a polydispersity value of 0.146 , and a zeta potential of $-56.0 \mathrm{mV}$. This high zeta potential value may be explained by the presence of both the triazole ring and amide bonds towards the exterior of the particles, as expected by the technique employed for their formation.

\section{Materials and Methods}

All reagents used were purchased from Sigma-Aldrich/Merck, Carbosynth or Fluka. The solvents used as reaction media were dried according to the procedures described in the literature [45]. Briefly, DMF was dried with barium oxide, filtered, distilled and stored with $3 \AA$ molecular sieves. Dichloromethane (DCM) was distilled from calcium hydride under an argon atmosphere and used immediately. Propargyl alcohol was dried overnight with potassium carbonate, distilled and used immediately. PEG was purchased from Sigma-Aldrich, with an average molecular weight of 1000 . D,L-poly(lactic-glycolic acid) (PLGA) 50:50, with a molecular weight range of 7000-17,000 was purchased from Sigma-Aldrich. Column chromatography was performed using Carlo Erba's silica gel, 40-63 $\mu \mathrm{m}$ mesh. Preparative TLC was performed using silica gel 60GF DGF254 purchased from Macherey-Nagel.

\subsection{Methods for Compounds Characterization}

Melting points were measured using an Electrothermal Melting Point Apparatus. Optical rotations were measured using a Bellingham and Stanley Ltd (Department of Chemistry FCT-NOVA; Portugal). ADP410 Polarimeter, at sodium D line (Department of Chemistry FCT-NOVA; Portugal). Nuclear magnetic resonance spectra were obtained using a Bruker ARX $400 \mathrm{MHz}$ (Department of Chemistry FCT-NOVA; Portugal) for ${ }^{1} \mathrm{H}$ and $101 \mathrm{MHz}$ for ${ }^{13} \mathrm{C}$. FT-IR spectra were recorded using a Bruker Tensor 27 (Department of Chemistry FCT-NOVA; Portugal). UV spectra were recorded on a Perkin Elmer Lambda 35 (Department of Chemistry FCT-NOVA; Portugal, using a quartz cell (Department of Chemistry FCT-NOVA; Portugal). Emission data were recorded on a Perkin Elmer LS 45 Luminescence Spectrometer, using a quartz cell (Department of Chemistry FCT-NOVA; Portugal). High resolution mass spectra were recorded on a Bruker Microtof using electrospray ionization, flow injection analysis and time-of-flight detector. MALDI spectra were recorded on a Bruker Ultraflex III TOF/TOF using HCCA as the matrix (Unidade de Espectrometria de Massas e Proteómica; Spain). DLS and zeta potential measurements were performed using Horiba Scientific Nano Particle Analyzer SZ-100 (Department of Chemistry FCT-NOVA; Portugal) with $1 \mathrm{mg}$ of particles in $1 \mathrm{~mL}$ of filtered, ultra-pure water, at $25^{\circ} \mathrm{C}$. SEM micrographs were obtained with a JEOL JSM 7001 scanning electron microscope 
(Electron Microscopy Laboratory of Instituto Superior Técnico; Portugal) with an accelerating voltage of $10 \mathrm{kV}$, after chromium-coating under argon atmosphere the previously fixed samples onto metallic studs.

\subsection{Nanoparticles Preparation}

Polymer matrix (50 mg) was dissolved in $5 \mathrm{~mL}$ of DCM and poured into $8.0 \mathrm{~mL}$ of aqueous PVA $2 \%$. The resulting oil-in-water preparation was sonicated at $60 \mathrm{~W}$ for a minute, in periods of $10 \mathrm{~s}$. The resulting emulsion was magnetically stirred overnight. The resulting suspension was centrifuged, and the pellet was washed three times with deionized water.

\subsection{Synthetic Procedures}

\subsubsection{Ethyl 3-(7-Hydroxy-4,8-Dimethyl-2-oxo-2H-Chromen-3-yl)propanoate (1)}

3-Methylresorcinol (11.020 g, $96.9 \mathrm{mmol})$ was dissolved in dry ethanol (50 $\mathrm{mL})$ with magnetic stirring. Diethyl 2-acetylglutarate $(21.0 \mathrm{~mL}, 96.7 \mathrm{mmol})$ was added and the reaction flask was cooled to $0{ }^{\circ} \mathrm{C}$ and dried hydrogen chloride was passed through the flask for $3 \mathrm{~h}$, and the reaction mixture was maintained at ambient temperature for $16 \mathrm{~h}$. Cool water $(500 \mathrm{~mL})$ was added and the resulting precipitate was collected and dried, affording $1(16.833 \mathrm{~g}, 60 \%)$ as a beige solid. m.p. $=145-148{ }^{\circ} \mathrm{C}$; FT-IR (NaCl) $\bar{v}_{\text {max }}: 3263$ (br, OH st), 2983 (s, C-H w), 1731-1703 (s, O-C=O st), 1619 (br, C=C m) cm ${ }^{-1}$;

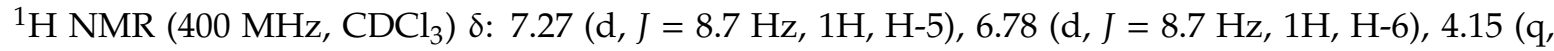
$J=7.1 \mathrm{~Hz}, 2 \mathrm{H}, \mathrm{H}-16), 2.98(\mathrm{t}, J=7.6 \mathrm{~Hz}, 2 \mathrm{H}, \mathrm{H}-13), 2.63(\mathrm{t}, J=7.5 \mathrm{~Hz}, 2 \mathrm{H}, \mathrm{H}-14), 2.40(\mathrm{~s}, 3 \mathrm{H}, \mathrm{H}-12), 2.27$

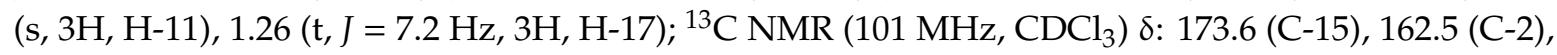
156.9 (C-7), 151.7 (C-9), 148.5 (C-4), 122.5 (C-5), 120.2 (C-3), 113.8 (C-10), 111.9 (C-6), 111.5 (C-8), 60.8 (C-16), 32.9 (C-14), 23.2 (C-13), 15.0 (C-12), 14.2 (C-17), 8.0 (C-11).

\subsubsection{Ethyl 3-(4,8-Dimethyl-2-oxo-7-(Prop-2-yn-1-yloxy)-2H-Chromen-3-yl)propanoate (2)}

Compound $1(0.992 \mathrm{~g}, 3.4 \mathrm{mmol})$ was dissolved in dry acetone $(8.3 \mathrm{~mL})$, and anhydrous potassium carbonate $(1.665 \mathrm{~g}, 12.1 \mathrm{mmol})$ was added. The reaction mixture was kept under constant stirring for $30 \mathrm{~min}$, and then propargyl bromide $(0.5 \mathrm{~mL}, 4 \mathrm{mmol})$ was added and the mixture was refluxed for $4 \mathrm{~h}$. After cooling to room temperature, the solvent was evaporated and the crude product was dissolved in DCM $(10 \mathrm{~mL})$, washed four times with deionized water $(4 \times 15 \mathrm{~mL})$, dried over anhydrous sodium sulfate, filtered and evaporated, affording $2(1.093 \mathrm{~g}, 98 \%)$ as a beige solid m.p. $=151-152{ }^{\circ} \mathrm{C} ;{ }^{1} \mathrm{H}$ NMR $\left(400 \mathrm{MHz}_{\mathrm{CDCl}}\right) \delta: 7.45(\mathrm{~d}, J=8.9 \mathrm{~Hz}, 1 \mathrm{H}, \mathrm{H}-5), 6.96(\mathrm{~d}, J=8.9 \mathrm{~Hz}, 1 \mathrm{H}, \mathrm{H}-6), 4.80(\mathrm{~d}, J=2.4 \mathrm{~Hz}, 2 \mathrm{H}$, H-1'), 4.12 (q, J = 7.1 Hz, 2H, H-16), 2.97 (t, J = 7.6 Hz, 2H, H-13), 2.60 (t, J = 7.7 Hz, 2H, H-14), 2.54 (t, $\left.J=2.5 \mathrm{~Hz}, 1 \mathrm{H}, \mathrm{H}-3^{\prime}\right), 2.43$ (s, 3H, H-12), 2.32 (s, 3H, H-11), 1.24 (t, J = 7.1 Hz, 3H, H-17); ${ }^{13} \mathrm{C}$ NMR (101

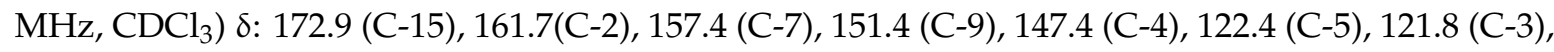
115.0 (C-10), 114.7 (C-8), 108.2 (C-6), 78.2 (C-2'), 76.0 (C-3'), 60.5 (C-16), 56.4 (C-1'), 32.7 (C-13), 23.2 (C-14), 15.0 (C-12), 14.21 (C-17), 8.3 (C-11).

\subsubsection{3-(4,8-Dimethyl-2-oxo-7-(Prop-2-yn-1-yloxy)-2H-Chromen-3-yl)propanoic Acid (3)}

Compound $2(0.822 \mathrm{~g}, 2.5 \mathrm{mmol})$ was dissolved in ethanol $(20.0 \mathrm{~mL})$, and $0.25 \mathrm{M}$ sodium hydroxide aqueous solution $(12 \mathrm{~mL})$ was added. The reaction was stirred at $80^{\circ} \mathrm{C}$ for $1 \mathrm{~h}$, cooled down to room temperature, and deionized water $(20 \mathrm{~mL})$ was added. The mixture was acidified with $1 \mathrm{M}$ hydrochloric acid to $\mathrm{pH} 1$ and the precipitate obtained was filtered and the resulting solid was dried, affording 3 (0.712 g, 95\%) as a white solid. m.p. = $181-183{ }^{\circ} \mathrm{C}$; FT-IR (NaCl) $\bar{v}_{\max }:: 3389$ (br, OH st), 3055 (s, C-H w), 2943 (s, C-H w), 2228 (br, C $\equiv \mathrm{C} \mathrm{st}$ ), 1763-1704 (s, O-C=O st), 1641 (br, C=C m) cm ${ }^{-1} ;{ }^{1} \mathrm{H}$ NMR (400 MHz, DMSO-d $\left.)_{6}\right) \delta: 63(\mathrm{~d}, J=8.9 \mathrm{~Hz}, 1 \mathrm{H}, \mathrm{H}-5), 7.10(\mathrm{~d}, J=9.0 \mathrm{~Hz}, 1 \mathrm{H}, \mathrm{H}-6), 4.95(\mathrm{~s}, 2 \mathrm{H}$, H-1'), $3.61\left(\mathrm{t}, J=2.7 \mathrm{~Hz}, 1 \mathrm{H}, \mathrm{H}-3^{\prime}\right), 2.77$ (t, J = 7.8 Hz, 2H, H-13), 2.40-2.35 (m, 4H, H-12,14), 2.18 (s, 3H, H-11); ${ }^{13} \mathrm{C}$ NMR (101 MHz, DMSO-d 6 ) $\delta: 173.8$ (C-15), 160.7 (C-2), 157.0 (C-7), 150.5 (C-9), 147.7 (C-4), 123.3 (C-5), 121.2 (C-3), 114.3 (C-10), 112.6 (C-8), 108.8 (C-6), 79.0 (C-2'), 78.7 (C-3'), 56.3 (C-1'), 32.6 (C-14), 23.0 (C-13), 14.7 (C-12), 8.0 (C-11). 


\subsubsection{7-(Prop-2-yn-1-yloxy)-2H-Chromen-2-One (4)}

Potassium iodide $(2.454 \mathrm{~g}, 14.7 \mathrm{mmol})$ and potassium carbonate $(2.045 \mathrm{~g}, 14.7 \mathrm{mmol})$ were added to a solution of umbelliferone $(2.011 \mathrm{~g}, 12.4 \mathrm{mmol})$ in DMF $(30 \mathrm{~mL})$ under magnetic stirring and argon atmosphere. Then, propargyl bromide $80 \%$ in toluene $(1.7 \mathrm{~mL}, 14.8 \mathrm{mmol})$ was added drop-wise and the reaction was heated at $80^{\circ} \mathrm{C}$. After the completion of the reaction $(2 \mathrm{~h} 30 \mathrm{~min})$, dichloromethane was added $(40 \mathrm{~mL})$ and the mixture was transferred to a separating funnel and washed three times with water $(3 \times 20 \mathrm{~mL})$. The organic phase was dried over anhydrous sodium sulfate, filtered and concentrated to afford 7-(prop-2-yn-1-yloxy)-2H-chromen-2-one, 4, as a light brown solid (2.382 g, 96\% without purification) and was used, as such, for further reactions. m.p. $=114-115^{\circ} \mathrm{C} ; \mathrm{UV}$ (DCM) $\lambda_{\max }$ $=319 \mathrm{~nm} ; \mathrm{Em}(\mathrm{DCM}) \lambda_{\max }=386\left(\lambda_{\mathrm{exc}}=320 \mathrm{~nm}\right) ; \mathrm{FT}-\mathrm{IR}(\mathrm{NaCl}) \bar{v}_{\max }: 3266$ (C-H st), 3084 (ar C-H st), 2119 (C=C st), 1701 (C=O st), 1614 (C=C st) cm ${ }^{-1} ;{ }^{1} \mathrm{H}$ NMR $\left(400 \mathrm{MHz}, \mathrm{CDCl}_{3}\right) \delta: 7.65$ (d, J=9.5 Hz, $1 \mathrm{H}$, $\mathrm{H}-4), 7.41(\mathrm{~d}, J=8.5 \mathrm{~Hz}, 1 \mathrm{H}, \mathrm{H}-5), 7.02-6.81(\mathrm{~m}, 2 \mathrm{H}, \mathrm{H}-6$ and H-8), $6.28(\mathrm{~d}, J=9.5 \mathrm{~Hz}, 1 \mathrm{H}, \mathrm{H}-3), 4.77(\mathrm{~d}$, $J=2.3 \mathrm{~Hz}, 2 \mathrm{H}, \mathrm{H}-9), 2.58(\mathrm{t}, J=2.2 \mathrm{~Hz}, 1 \mathrm{H}, \mathrm{H}-11) ;{ }^{13} \mathrm{C} \mathrm{NMR}\left(101 \mathrm{MHz}, \mathrm{CDCl}_{3}\right) \delta: 161.0(\mathrm{C}-2), 160.6$ (C-7), 155.7 (C-8a), 143.3 (C-4), 128.8 (C-5), 113.7 (C-3), 113.2 (C-4a), 113.1 (C-6), 102.2 (C-8), 77.4 (C-10), 76.6 (C-11), $56.2(\mathrm{C}-9)$.

\subsubsection{Prop-2-yn-1-yl 2-oxo-2H-Chromene-3-Carboxylate (5)}

DCC $(2.600,12.6 \mathrm{mmol})$ and DMAP $(0.129 \mathrm{~g}, 1.1 \mathrm{mmol})$ were added to a solution of coumarin-3carboxylic acid $(2.000 \mathrm{~g}, 10.5 \mathrm{mmol})$ in DCM $(30 \mathrm{~mL})$. The reaction mixture was stirred magnetically under an argon atmosphere and propargyl alcohol $(1.2 \mathrm{~mL}, 21.0 \mathrm{mmol})$ was added drop-wise. After stirring overnight the mixture was filtered, transferred to a separating funnel and washed three times with acetic acid $(5 \%, 3 \times 15 \mathrm{~mL})$ and then with water $(20 \mathrm{~mL})$. The organic phase was dried over anhydrous sodium sulfate, filtered and the solvent evaporated under vacuum. The residue was washed with petroleum ether to afford the desired product as a white solid (2.399 g quantitative yield without purification) and used for further reactions. m.p. $=125-127^{\circ} \mathrm{C} ; \mathrm{UV}(\mathrm{DCM}) \lambda_{\max }=294 \mathrm{~nm} ; \mathrm{Em}(\mathrm{DCM})$ $\lambda_{\max }=418\left(\lambda_{\text {exc }}=320 \mathrm{~nm}\right)$; FT-IR $(\mathrm{NaCl}) \bar{v}_{\max }:: 3315,3228$ (C $\equiv \mathrm{C}-\mathrm{H}$ st), 3058 (ar C-H st), 2936, 2852, 2117

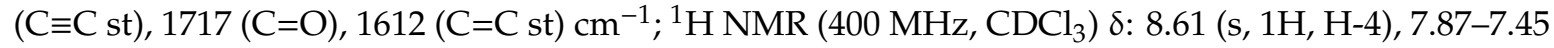
(m, 2H, H-5 and H-7), 7.36 (m, 2H, H-6 and H-8), 4.95 (d, J = 2.1 Hz, 2H, H-9), 2.56 (t, J = 2.0 Hz, 1H, H-11); ${ }^{13} \mathrm{C}$ NMR (101 MHz, CDCl 3 ) 8: 162.1 (C-9), 156.4 (C-2), 155.3 (C-8a), 149.6 (C-7), 134.8 (C-5), 129.7 (C-4), 125.0 (C-6), 117.7 (C-4a), 117.2 (C-8), 116.9 (C-3), 75.7 (C-12), 53.2 (C-10). C-11 is probably obscured by the $\mathrm{CDCl}_{3}$ signal.

\subsubsection{4-Methyl-7-(Prop-2-yn-1-yloxy)-2H-Chromen-2-One (6)}

7-Hydroxy-4-methyl coumarin $(3.532 \mathrm{~g}, 20.1 \mathrm{mmol})$ was dissolved in dry acetone $(30 \mathrm{~mL})$ and anhydrous potassium carbonate $(3.209 \mathrm{~g}, 20.2 \mathrm{mmol})$ was added. The reaction was magnetically stirred for $30 \mathrm{~min}$, and propargyl bromide $(2.7 \mathrm{~mL}, 24.1 \mathrm{mmol})$ was added. The reaction flask was heated at $50^{\circ} \mathrm{C}$ and reacted for $18 \mathrm{~h}$. The solvent was evaporated, and the residue was dissolved in DCM $(20 \mathrm{~mL})$ and washed four times with water $(20 \mathrm{~mL})$. The organic phase was dried over anhydrous sodium sulfate, filtered and evaporated, to afford product $6(3.786 \mathrm{~g}, 88 \%)$ as a beige solid. m.p. $=132-134{ }^{\circ} \mathrm{C}$; FT-IR (NaCl) $\bar{v}_{\max }: 3304$ (s, 三C-H, st), 3069 (s, C-H m), 2924 (s, C-H m), 1764-1721 (s, O-C=O st), 1619 (br, C=C m), $1262(\mathrm{~s}, \mathrm{CO}-\mathrm{O} \mathrm{m}) \mathrm{cm}^{-1},{ }^{1} \mathrm{H}$ NMR $\left(400 \mathrm{MHz}, \mathrm{CDCl}_{3}\right) \delta: 7.52(\mathrm{~d}, J=9.5 \mathrm{~Hz}, 1 \mathrm{H}, \mathrm{H}-5)$, 7.00-6.80 (m, 2H, H-6,8), 6.15 (s, 1H, H-3), 4.76 (d, J = 2.5 Hz, 2H, H-1'), 2.59 (t, J = 2.5 Hz, 1H, H3'), 2.40 (s, 3H, H-11); ${ }^{13} \mathrm{C}$ NMR (101 MHz, CDCl 3 ) $\delta: 161.1$ (C-2), 160.4 (C-7), 155.0 (C-4), 152.5 (C-9), 125.7 (C-5), 114.3 (C-10), 112.7 (C-6), 112.4 (C-3), 102.2 (C-8), 77.5 (C-2'), 76.5 (C-3'), 56.2 (C-1'), 18.7 (C-11).

\subsubsection{2-Azidoethanamine (7)}

2-Bromoethylamine hydrobromide $(6.162 \mathrm{~g}, 30.1 \mathrm{mmol})$ was added to an aqueous sodium azide solution $(3.5 \mathrm{M}, 26 \mathrm{~mL})$. The reaction was kept at $85^{\circ} \mathrm{C}$ for $21 \mathrm{~h}$, and then cooled to $0{ }^{\circ} \mathrm{C}$. Potassium hydroxide $(7.985 \mathrm{~g}, 142.3 \mathrm{mmol})$ was then added in three portions and the $\mathrm{pH}$ reached 10 . The compound 
was extracted with diethyl ether $(4 \times 25 \mathrm{~mL})$ and the organic phase was dried over anhydrous sodium sulfate, filtered and the solvent evaporated at $28^{\circ} \mathrm{C}$ to a green mixture of $2.688 \mathrm{~g}$ containing $2.105 \mathrm{~g}$ ( $24.4 \mathrm{mmol}, 81 \%$ ) of the desired compound in ether. The yield of this reaction was determined by NMR. The solvent was never fully evaporated due to the sensitive and explosive nature of 7 . FT-IR $(\mathrm{NaCl})$ $\bar{v}_{\text {max }}: 3447$ (br, N-H st), 2939 (s, C-H w), 2093 (s, N $\left.\mathrm{N}_{3} \mathrm{st}\right) \mathrm{cm}^{-1} ;{ }^{1} \mathrm{H}$ NMR $\left(400 \mathrm{MHz}, \mathrm{CDCl}_{3}\right)$ 8: 3.36 (t, $J=5.7 \mathrm{~Hz}, 2 \mathrm{H}, \mathrm{H}-2), 2.87(\mathrm{t}, J=5.7 \mathrm{~Hz}, 2 \mathrm{H}, \mathrm{H}-1), 1.71\left(\mathrm{~s}, 2 \mathrm{H}, \mathrm{NH}_{2}\right) ;{ }^{13} \mathrm{C} \mathrm{NMR}\left(101 \mathrm{MHz}, \mathrm{CDCl}_{3}\right) \delta: 54.7$ (C-2), $41.4(\mathrm{C}-1)$.

\subsubsection{7-((1-(2-Aminoethyl)-1H-1,2,3-Triazol-4-yl)methoxy)-4-Methyl-2H-Chromen-2-One (8)}

Compound 7 (0.534 g, $6.2 \mathrm{mmol})$ was dissolved in freshly distilled THF (6.0 mL). DIPEA $(0.2 \mathrm{~mL})$, copper iodide $(0.044 \mathrm{~g}$, cat. $)$ and 6 ( $2.657 \mathrm{~g} ; 12.4 \mathrm{mmol})$ were added. The mixture was kept under magnetic stirring for $1.5 \mathrm{~h}$. The mixture was purified by silica gel chromatography using chloroform/methanol (8: 2) as eluent, affording 8 as a yellow solid $(1.396$ g, $75 \%)$. m.p. $=114-116^{\circ} \mathrm{C}$; ${ }^{1} \mathrm{H}$ NMR (400 MHz, DMSO-d 6 ) $\delta: 8.26$ (s, 1H, H-5), 7.69 (d, J = 8.8 Hz, 1H, H-5'), 7.15 (d, J = 2.5 Hz, $\left.1 \mathrm{H}, \mathrm{H}-3^{\prime}\right), 7.04\left(\mathrm{dd}, J=8.8,2.4 \mathrm{~Hz}, 1 \mathrm{H}, \mathrm{H}-6^{\prime}\right), 6.22\left(\mathrm{t}, J=1.3 \mathrm{~Hz}, 1 \mathrm{H}, \mathrm{H}-8^{\prime}\right), 5.26(\mathrm{~s}, 2 \mathrm{H}, \mathrm{H}-6), 4.34(\mathrm{t}$, $J=6.2 \mathrm{~Hz}, 2 \mathrm{H}, \mathrm{H}-2), 2.97(\mathrm{t}, J=6.2 \mathrm{~Hz}, 2 \mathrm{H}, \mathrm{H}-1), 2.40\left(\mathrm{~d}, J=1.3 \mathrm{~Hz}, 3 \mathrm{H}, \mathrm{H}-11^{\prime}\right), 1.90\left(\mathrm{~s}, 2 \mathrm{H}, \mathrm{NH}_{2}\right) ;{ }^{13} \mathrm{C}$ NMR (101 MHz, DMSO-d 6 ) 8: 161.1 (C-2'), 160.1 (C-7'), 154.7 (C-4'), 153.4 (C-9'), 141.7 (C-4), 126.5 (C-5'), 125.1 (C-5), 113.4 (C-14'), 112.6 (C-6'), 111.3 (C-8'), 101.6 (C-3'), 61.7 (C-6), 54.9 (C-2), 52.5 (C-1), 18.1 (C-11'); MS (ESI+) m/z: calc: for $\mathrm{C}_{15} \mathrm{H}_{17} \mathrm{~N}_{4} \mathrm{O}_{3}\left(\mathrm{M}+\mathrm{H}^{+}\right)$301.1295, found 301.1299.

\subsubsection{1-O-Propargyl-D-Glucopyranoside (9)}

D-glucose (4.149 g, $23.0 \mathrm{mmol})$ was dissolved in propargyl alcohol $(7.8 \mathrm{~mL}, 132.0 \mathrm{mmol})$, and sulfuric acid immobilized in silica gel $(150.4 \mathrm{mg})$ was added. The reaction mixture was heated at $65^{\circ} \mathrm{C}$ overnight. After cool down to room temperature, the mixture was purified by silica column chromatography using an ethyl acetate/acetone/water (10:10:1) mixture, affording 9 as a mixture of $\alpha$ and $\beta$ anomers, 2:1 ratio. Sulfuric acid supported on silica was prepared accordingly with the procedure described by Roy and Mukhopadhyay [36]. For detailed characterization, the $\alpha, \beta$ mixture 9 was per-O-acetylated using acetic anhydride to give the $\alpha, \beta$-propargylated per-acetylated glucopyranose 12.

\subsubsection{1-O-Propargyl-D-Galactopyranoside (10)}

D-galactose (2.000 g, $11.1 \mathrm{mmol})$, propargyl alcohol $(3.2 \mathrm{~mL}, 55.6 \mathrm{mmol})$ and sulfuric acid supported on silica $(72.5 \mathrm{mg})$ were mixed together under magnetic stirring and an argon atmosphere. The reaction flask was heated at $65^{\circ} \mathrm{C}$ overnight, and after cooling the mixture was chromatographed [ethyl acetate (AcOEt), then 10:10:1 AcOEt/acetone/water] affording 45\% of propargylated galactopyranose $\mathbf{1 0}$ as a yellowish oil (1.099 $\mathrm{g}, 0.5 \mathrm{mmol}, 2: 1 \alpha / \beta$ ratio). Sulfuric acid supported on silica was prepared accordingly with the procedure described by Roy and Mukhopadhyay [36]. $[\alpha]_{D}^{16}=+110.0^{\circ}(\mathrm{C}=1.4$, $\mathrm{MeOH}) ;$ FT-IR $(\mathrm{NaCl}), \bar{v}_{\text {max }}: 3382$ (br, O-H st), 2925 (w, C-H st) cm ${ }^{-1} ;{ }^{1} \mathrm{H}$ NMR $\left(400 \mathrm{MHz}, \mathrm{D}_{2} \mathrm{O}\right) \delta: 5.04$ $(\mathrm{s}, 2 \mathrm{H}, \mathrm{H}-1 \alpha), 4.50(\mathrm{~d}, J=7.9 \mathrm{~Hz}, 1 \mathrm{H}, \mathrm{H}-1 \beta), 4.43-4.39(\mathrm{~m}, 1 \mathrm{H}), 4.26(\mathrm{dd}, J=5.8,2.2 \mathrm{~Hz}, 4 \mathrm{H}), 3.92(\mathrm{~s}, 2 \mathrm{H})$, 3.91-3.83 (m, 3H), 3.81-3.74 (m, 5H), 3.72-3.63 (m, 7H), 3.59 (dd, $J=9.9,3.3 \mathrm{~Hz}, 1 \mathrm{H}), 3.50-3.41(\mathrm{~m}, 1 \mathrm{H})$, 2.86-2.80 (m, 1H); ${ }^{13} \mathrm{C}$ NMR (101 MHz, $\left.\mathrm{D}_{2} \mathrm{O}\right) \delta: 101.1,97.3,79.0,78.9,76.2,75.9,75.3,72.7,71.2,70.5$, $69.4,69.1,68.6,67.9,60.9,60.9,56.5,54.8$.

\subsubsection{1-O-Propargyl-D-Mannopyranoside (11)}

D-mannose (2.000 g, $11.1 \mathrm{mmol})$, propargyl alcohol ( $3.2 \mathrm{~mL}, 55.6 \mathrm{mmol})$ and sulfuric acid supported on sílica $(58 \mathrm{mg})$ were mixed together under magnetic stirring and argon atmosphere. The reaction flask was heated at $65^{\circ} \mathrm{C}$ overnight, and after cooling the mixture was purified by column chromatography (AcOEt, then 10:10:1 AcOEt/acetone/water) affording propargylated mannopyranose $\mathbf{1 1}$ as a yellowish oil $(0.928 \mathrm{~g}, 38 \%, 2: 1 \alpha / \beta$ ratio). Sulfuric acid supported on silica was prepared accordingly to the procedure described by Roy and Mukhopadhyay [36]. FT-IR (NaCl), $\bar{v}_{\text {max }}: 3289$ (br), 2930 (w) cm cm $^{-1}$ 
${ }^{1} \mathrm{H}$ NMR $\left(400 \mathrm{MHz}, \mathrm{D}_{2} \mathrm{O}\right)$ 8: 5.00 (s, 1H, H-1 $\left.\alpha\right), 4.40-4.20$ (m, 2H, H-1'), $3.92(\mathrm{~s}, 1 \mathrm{H}), 3.89-3.81(\mathrm{~m}, 1 \mathrm{H})$, 3.81-3.69 (m, 2H), 3.69-3.57 (m, 2H), $2.89\left(\mathrm{~s}, 1 \mathrm{H}, \mathrm{C}-3^{\prime}\right) ;{ }^{13} \mathrm{C}$ NMR (101 MHz, $\left.\mathrm{D}_{2} \mathrm{O}\right)$ 8: $98.7(\mathrm{C}-1 \alpha), 79.0$, $76.3,73.1,70.5,69.9,66.6,60.8,54.6\left(\mathrm{C}-1^{\prime}\right)$.

\subsubsection{1-O-Propargyl-2,3,4,6-Tetra-O-Acetyl-D-Glucopyranoside (12)}

Glucopyranoside 9 (3.418 g, $15.7 \mathrm{mmol}$ ) reacted with acetic anhydride $(16.2 \mathrm{~mL}, 171.6 \mathrm{mmol})$ in dry pyridine $(30.0 \mathrm{~mL})$ for $4 \mathrm{~h}$ under an argon atmosphere. The solvent was then evaporated and the remaining solid was dissolved in dichloromethane and purified by silica column chromatography using hexane/ethyl acetate (1:1) affording 12 as a colorless oil $(4.998 \mathrm{~g}, 82 \%)$. FT-IR $(\mathrm{NaCl}) \bar{v}_{\text {max }}: 3278$ (s, $\equiv \mathrm{C}-\mathrm{H} \mathrm{w}), 2961$ (s, C-H w), 1749 (s, O-C=O st) cm ${ }^{-1} ;{ }^{1} \mathrm{H} \mathrm{NMR}\left(400 \mathrm{MHz}, \mathrm{CDCl}_{3}\right) \delta: 5.49(\mathrm{t}, J=9.8 \mathrm{~Hz}$, 1.17H, H-3), 5.30-5.27 (m, 1H, H-1 $\alpha), 5.15-4.97(\mathrm{~m}, 2 \mathrm{H}), 4.92(\mathrm{dd}, J=10.3,3.8 \mathrm{~Hz}, 1 \mathrm{H}), 4.78(\mathrm{~d}, J=8.0 \mathrm{~Hz}$, $0.42 \mathrm{H} \mathrm{H}-1 \beta), 4.38(\mathrm{~d}, J=2.3 \mathrm{~Hz}, 1 \mathrm{H}), 4.28\left(\mathrm{~d}, J=2.4 \mathrm{~Hz}, 2 \mathrm{H}, \mathrm{H}-1^{\prime}\right), 4.26(\mathrm{~d}, J=4.1 \mathrm{~Hz}, 1 \mathrm{H}), 4.18-4.03(\mathrm{~m}$, $3 \mathrm{H}), 3.78-3.70(\mathrm{~m}, 0.42 \mathrm{H}, \mathrm{H}-5 \beta), 2.48\left(\mathrm{t}, J=2.3 \mathrm{~Hz}, 0.41 \mathrm{H}, \mathrm{H}-3^{\prime} \beta\right), 2.46\left(\mathrm{t}, J=2.3 \mathrm{~Hz}, 1 \mathrm{H}, \mathrm{H}-3^{\prime} \alpha\right), 2.06(\mathrm{~s}$, $\left.19 \mathrm{H}, \mathrm{CH}_{3}\right)$.

\subsubsection{1-[1'-Ethylamine-Triazolyl-4]-1-Methyl-2,3,4,6-Tetra-O-Acetyl-D-Glucopyranoside (13)}

Compound 7 (0.037 $\mathrm{g}, 0.4 \mathrm{mmol})$ was dissolved in $4,0 \mathrm{~mL}$ of freshly distilled THF, and DIPEA $(0.1 \mathrm{~mL}, 0.6 \mathrm{mmol})$, copper iodide $(0.027 \mathrm{~g}$, cat. $)$ and $12(0.237 \mathrm{~g}, 0.6 \mathrm{mmol})$ were added. After $2.5 \mathrm{~h}$ the solvent was evaporated and the mixture was purified by column chromatography using chloroform/methanol (9:1), affording $13(0.138,73 \%)$ as a yellow solid. m.p. $=60-65^{\circ} \mathrm{C}$ (degradation); FT-IR (NaCl) $\bar{v}_{\text {max: }} 3421$ (br, NH st), 1745 (s, O-C $\left.=\mathrm{O} \mathrm{st}\right) \mathrm{cm}^{-1} ;{ }^{1} \mathrm{H}$ NMR $\left(400 \mathrm{MHz}, \mathrm{CDCl}_{3}\right) \delta: 7.68$ (s, $\left.1 \mathrm{H}, \mathrm{H}_{\alpha}-5^{\prime}\right), 7.64\left(\mathrm{~s}, 0.48 \mathrm{H}, \mathrm{H}_{\beta}-5^{\prime}\right), 5.49(\mathrm{t}, J=9.8 \mathrm{~Hz}, 1 \mathrm{H}, \mathrm{H}-3), 5.22\left(\mathrm{~d}, J=4.1 \mathrm{~Hz}, 1 \mathrm{H}, \mathrm{H}-1_{\alpha}\right), 5.09(\mathrm{~s}$, $1 \mathrm{H}, \mathrm{H}-2), 4.91-4.83(\mathrm{~m}, 3 \mathrm{H}),, 4.70\left(\mathrm{~d}, J=12.5 \mathrm{~Hz}, 2 \mathrm{H}, \mathrm{H}-1_{\beta}, 6\right), 4.44\left(\mathrm{t}, J=5.9 \mathrm{~Hz}, 3 \mathrm{H}, \mathrm{H}-7^{\prime}\right), 4.31-4.22$ $(\mathrm{m}, 2 \mathrm{H}), 4.11(\mathrm{dd}, J=10.1,3.1 \mathrm{~Hz}, 2.38 \mathrm{H}), 3.75(\mathrm{~d}, J=7.8 \mathrm{~Hz}, 0.8 \mathrm{H}, \mathrm{H}-5), 3.26\left(\mathrm{~s}, 3 \mathrm{H}, \mathrm{H}-8^{\prime}\right), 2.13-1.98$ $\left(\mathrm{m}, 20 \mathrm{H}, \mathrm{CH}_{3}\right) ;{ }^{13} \mathrm{C}$ NMR $\left(101 \mathrm{MHz}, \mathrm{CDCl}_{3}\right) \delta: 170.7-169.5$ (C-Ac), $144.1\left(\mathrm{C}-4^{\prime} \beta\right), 143.5\left(\mathrm{C}-4^{\prime} \alpha\right), 123.7$ $\left(C-5^{\prime} \beta\right), 123.6\left(C-5^{\prime} \alpha\right), 99.9(C-1 \alpha), 95.0(C-1 \beta), 72.8-72.0(C-5), 71.9-71.3(C-2), 70.7-70.6(C-3), 68.5-68.3$ (C-6), $67.5(\mathrm{C}-4), 63.0\left(\mathrm{C}-6^{\prime}\right), 61.8(\mathrm{C}-6 \beta), 61.3(\mathrm{C}-6 \alpha), 60.8\left(\mathrm{C}-7^{\prime}\right), 41.7\left(\mathrm{C}-8^{\prime}\right), 20.8-20.6\left(\mathrm{CH}_{3}\right)$.

\subsubsection{1-[1'-Ethylamine-Triazolyl-4]-1-O-Methyl-D-Glucopyranoside (14)}

Compound 13 ( $0.110 \mathrm{~g}, 0.2 \mathrm{mmol})$ was dissolved in dry methanol at ice-bath temperature, and sodium methoxide was added $(0.012 \mathrm{~g}, 0.2 \mathrm{mmol})$. The reaction was allowed to warm to room temperature and stirred for a further $3 \mathrm{~h}$. Pre-activated and thoroughly washed acidic Dowex was added until the $\mathrm{pH}$ changed from basic to acidic. The solution was filtered and the solvent evaporated to give compound $14(0.071 \mathrm{~g}, 0.2 \mathrm{mmol}, 100 \%)$ as a white foam. Due to the complex anomeric mixture this compound's characterization was based on the spectra of per-O-acetyl compound $\mathbf{1 3}$.

\subsubsection{5'-O-[(4-Methylphenyl)sulfonyl] Thymidine (15)}

In a round bottom flask 2'-deoxythymidine $(1.569 \mathrm{~g}$, $6.5 \mathrm{mmol})$ was dissolved in dry pyridine $(7.5 \mathrm{~mL})$ and the flask cooled in an ice bath for $1 \mathrm{~h}$. Tosyl chloride $(1.236 \mathrm{~g}, 6.5 \mathrm{mmol})$ dissolved in dry pyridine $(2.5 \mathrm{~mL})$ was added dropwise and the reaction allowed to attain room temperature during 17 $\mathrm{h}$. The solvent was then evaporated, and the resulting crude product was dissolved in ethanol at $75{ }^{\circ} \mathrm{C}$ and then cooled down to $-10{ }^{\circ} \mathrm{C}$ for $12 \mathrm{~h}$. The resulting crystals of 15 were filtered and washed with cold ethanol $(3 \times 1.0 \mathrm{~mL}, 1.889 \mathrm{~g}, 54 \%)$. m.p. $=189-191{ }^{\circ} \mathrm{C}$; FT-IR $(\mathrm{NaCl}) \bar{v}_{\text {max }}: 3374$ (br, OH st), 3067 (s, C-H w), 2924 (s, C-H w), 1724-1694 (s, N-C=O st) cm ${ }^{-1} ;{ }^{1} \mathrm{H}$ NMR $\left(400 \mathrm{MHz}, \mathrm{DMSO}-\mathrm{d}_{6}\right) \delta: 11.31(\mathrm{~s}, 1 \mathrm{H}$, $\mathrm{NH}), 7.79(\mathrm{~d}, J=8.2 \mathrm{~Hz}, 2 \mathrm{H}, \mathrm{H}-12), 7.47(\mathrm{~d}, J=8.1 \mathrm{~Hz}, 2 \mathrm{H}, \mathrm{H}-13), 7.38(\mathrm{~s}, 1 \mathrm{H}, \mathrm{H}-6), 6.15(\mathrm{t}, J=6.9 \mathrm{~Hz}$, $1 \mathrm{H}, \mathrm{H}-1), 5.43(\mathrm{~d}, J=4.2 \mathrm{~Hz}, 1 \mathrm{H}, \mathrm{OH}), 4.26(\mathrm{dd}, J=10.9,3.2 \mathrm{~Hz}, 1 \mathrm{H}, \mathrm{H}-3), 4.19-4.15$ (m, 2H, H-5), 3.86 $(\mathrm{dt}, J=6.8,3.5 \mathrm{~Hz}, 1 \mathrm{H}, \mathrm{H}-4), 2.41$ (s, 3H, H-15), 2.19-2.04 (M, 2H, H-2), 1.77 (s, 3H, H-8); ${ }^{13} \mathrm{C}$ NMR (101 MHz, DMSO-d 6 ) 8: 163.6 (C-9), 150.4 (C-10), 145.1 (C-11), 135.9 (C-14), 132.1 (C-6), 130.2 (C-13), 127.6 (C-12), 109.8 (C-7), 84.0 (C-1), 83.2 (C-4), 70.1 (C-3), 69.9 (C-5), 38.3 (C-2), 21.1 (C-15), 12.1 (C-8). 


\subsubsection{5'-Azide-5'-Deoxythymidine (16)}

Method I-conventional heating: compound $15(0.562 \mathrm{~g}, 1.4 \mathrm{mmol})$ was dissolved in DMF $(5.0 \mathrm{~mL})$, and sodium azide was added $(0.407 \mathrm{~g}, 6.4 \mathrm{mmol})$. The reaction mixture was heated to $85^{\circ} \mathrm{C}$ on an oil bath for $15 \mathrm{~h}$. The solvent was then evaporated under reduced pressure and the mixture was purified by silica gel column chromatography using chloroform/methanol (9:1) as eluent, affording $\mathbf{1 6}(0.325 \mathrm{~g}$, $87 \%)$ as a beige solid.

Method II-microwave irradiation: compound $15(0.817 \mathrm{~g}, 2.1 \mathrm{mmol})$ was dissolved in DMF $(5.0 \mathrm{~mL})$, and sodium azide $(0.620 \mathrm{~g}, 10.3 \mathrm{mmol})$ was added. The mixture was irradiated with microwaves with a power of $250 \mathrm{~W}$ at a temperature of $100{ }^{\circ} \mathrm{C}$, for two $1 \mathrm{~min}$ cycles. The solvent was evaporated under reduced pressure and the mixture was purified by column chromatography (chloroform/methanol, 9:1) to afford $16(0.505 \mathrm{~g}, 90 \%)$ as a beige solid. m.p. $=156-158{ }^{\circ} \mathrm{C}$; FT-IR $(\mathrm{NaCl}) \bar{v}_{\max }: 3422$ (br,OH st), 2926 (s, C-H w), 2103 (s, N3 st), 1701-1685 (s, N-C=O st) cm ${ }^{-1} ;{ }^{1} \mathrm{H}$ NMR $\left(400 \mathrm{MHz}, \mathrm{CD}_{3} \mathrm{OD}\right) \delta: 7.56(\mathrm{~s}, 1 \mathrm{H}, \mathrm{H}-6), 6.29(\mathrm{t}, J=6.8 \mathrm{~Hz}, 1 \mathrm{H}, \mathrm{H}-1), 4.38(\mathrm{dt}, J=6.5,4.1 \mathrm{~Hz}, 1 \mathrm{H}, \mathrm{H}-3)$, $3.99(\mathrm{q}, J=4.0 \mathrm{~Hz}, 1 \mathrm{H}, \mathrm{H}-4), 3.63(\mathrm{qd}, J=13.2,4.4 \mathrm{~Hz}, 2 \mathrm{H}, \mathrm{H}-5), 2.37-2.25(\mathrm{~m}, J=6.9 \mathrm{~Hz}, 2 \mathrm{H}, \mathrm{H}-2), 1.92$ (s, 3H, H-8); ${ }^{13} \mathrm{C}$ NMR (101 MHz, CD $\left.{ }_{3} \mathrm{OD}\right)$ 8: 166.3 (C-9), 152.3 (C-10), 137.8 (C-6), 111.9 (C-7), 86.4 (C-4), 86.3 (C-1), 72.5 (C-3), 53.4 (C-5), 40.2 (C-2), 12.5 (C-8).

\subsubsection{7. $\alpha$-Coumarin 3-Carboxylate- $\omega$-Hydroxyl PEG $_{1000}$ (17)}

Coumarin 3-carboxylic acid (0.456 g, $2.4 \mathrm{mmol})$ was dissolved in DCM (15 mL) with magnetic stirring and under an argon atmosphere. DCC (0.990 g, $4.8 \mathrm{mmol})$ and DMAP (0.293 g, $2.4 \mathrm{mmol})$ were added. After $45 \mathrm{~min}$, a white precipitate was observed and $\mathrm{PEG}_{1000}(2.000,2.0 \mathrm{mmol})$ was added. The reaction flask was heated at $40{ }^{\circ} \mathrm{C}$ for $18 \mathrm{~h}$. Then, the mixture was filtrated and washed two times with aqueous acetic acid 5\% $(2 \times 20 \mathrm{~mL})$ and once with water $(20 \mathrm{~mL})$. The organic phase was dried over sodium sulfate, filtered, concentrated and purified by column chromatography (chloroform to 9:1 chloroform/methanol gradient), affording the required product in $98 \%$ yield $(2.307 \mathrm{~g}, 1.97 \mathrm{mmol})$ as a yellowish wax. FT-IR ( $\mathrm{NaCl}), \bar{v}_{\max }: 3512$ (br, O-H st), 2870 (s, C-H st), 1766 (s, C=O st) cm ${ }^{-1}$; UV $(\mathrm{DCM}) \lambda_{\max }=292 \mathrm{~nm} ; \mathrm{Em}(\mathrm{DCM}) \lambda_{\max }=386 \mathrm{~nm}(\lambda \mathrm{exc}=320 \mathrm{~nm}) ;{ }^{1} \mathrm{H} \mathrm{NMR}\left(400 \mathrm{MHz}, \mathrm{CDCl}_{3}\right) \delta: 8.57$ (s, 1H, H-4), 7.65 (m, 2H, H-Ar), 7.36 (m, 2H, H-Ar), 4.50 (t, J = 4.6 Hz, 2H, O-C $\left.\underline{H}_{2}-\mathrm{PEG}\right), 3.85$ (t, 2H, $\mathrm{O}-\mathrm{CH}_{2} \mathrm{CH}_{2}$-PEG), 3.79-3.56 (m, 84H, PEG); ${ }^{13} \mathrm{C} \mathrm{NMR} \mathrm{(101} \mathrm{MHz,} \mathrm{CDCl}_{3}$ ) $\delta: 162.8$ (C-9), 156.6 (C-2), $155.2\left(\mathrm{C}-8^{\mathrm{a}}\right), 148.8,134.4$ (C-Ar), 129.6 (C-Ar), 124.9 (C-Ar), 119.9, 119.8 (C-3 and C-4a), 116.8 (C-Ar), 72.5 (PEG), 70.5 (PEG), 70.2 (PEG), $68.9\left(\mathrm{O}-\underline{C H}_{2}-\mathrm{CH}_{2}-\mathrm{PEG}\right), 64.8\left(\mathrm{O}-\mathrm{CH}_{2}-\underline{\mathrm{CH}_{2}}-\mathrm{PEG}\right), 61.6$ (PEG).

\subsubsection{8. $\alpha$-Coumarin 3-Carboxylate- $\omega$-Tosyl PEG $_{1000}$ (18)}

Polymer 17 ( $3.968 \mathrm{~g}, 3.4 \mathrm{mmol})$ was dissolved in DCM $(25 \mathrm{~mL})$ and triethylamine $(0.7 \mathrm{~mL}, 5.1 \mathrm{mmol})$ with magnetic stirring and argon atmosphere. Tosyl chloride $(0.965 \mathrm{~g}, 5.1 \mathrm{mmol})$ was then added slowly in portions. After $18 \mathrm{~h}$, the reaction mixture was evaporated and purified by column chromatography (chloroform to 9:1 $\mathrm{CHCl}_{3} /$ methanol, gradient), to afford $\mathbf{1 8}$ as a yellowish wax in $92 \%$ yield $(4.001 \mathrm{~g}, 3.0$ mmol). FT-IR ( $\mathrm{NaCl}), \bar{v}_{\text {max }}: 2872$ (s, C-H st), 1761 (s, C=O st), 1108 (s, O=S=O sym st) cm ${ }^{-1}$; UV (DCM) $\lambda_{\max }=285 \mathrm{~nm} ; \operatorname{Em}(\mathrm{DCM}) \lambda_{\max }=412.5 \mathrm{~nm}(\lambda \mathrm{exc}=320 \mathrm{~nm}) ;{ }^{1} \mathrm{H} \mathrm{NMR}\left(400 \mathrm{MHz}, \mathrm{CDCl}_{3}\right) \delta: 8.57(\mathrm{~s}, 1 \mathrm{H}$, $\mathrm{H}-4), 7.80$ (d, J = 8.2 Hz, 2H, H-Ar), 7.73-7.57 (m, 2H, H-Ar), 7.35 (m, 4H, H-Ar), 4.50 (t, J = 4.8 Hz, 4H, PEG), $4.16(\mathrm{t}, J=4.8 \mathrm{~Hz}, 2 \mathrm{H}, \mathrm{PEG}), 3.89-3.81(\mathrm{t}, J=4.8 \mathrm{~Hz}, 4 \mathrm{H}, \mathrm{PEG}), 3.76-3.49(\mathrm{~m}, 120 \mathrm{H}, \mathrm{PEG}), 2.45(\mathrm{~s}$, $\left.3 \mathrm{H}, \mathrm{CH}_{3}\right) ;{ }^{13} \mathrm{C}$ NMR $\left(101 \mathrm{MHz}, \mathrm{CDCl}_{3}\right)$ ) $: 162.8$ (C-9), 156.6, 155.2, 148.9 (C-4), 144.8, 134.5, 133.0, 129.8, 129.6, 128.0, 124.9, 117.9, 117.8, 116.8, 70.7, 70.6, 70.6, 70.5 (PEG), 69.3 (PEG), 68.9 (PEG), 68.6 (PEG), 64.9 (PEG), 21.6 (C-14).

\subsubsection{9. $\alpha$-Coumarin 3-Carboxylate- $\omega$-Azide PEG $_{1000}$ (19)}

Polymer 18 ( $4.008 \mathrm{~g}$, $3.0 \mathrm{mmol})$ was dissolved in DMF ( $32 \mathrm{~mL})$ and sodium azide $(0.393 \mathrm{~g}, 6.0 \mathrm{mmol})$ was added in portions with stirring under an argon atmosphere. After $18 \mathrm{~h}$, the DMF was evaporated under reduced pressure and water was added to the resulting residue. The mixture was extracted 
with DCM, dried over anhydrous sodium sulfate, filtered, concentrated and purified by column chromatography (chloroform to 9:1 chloroform/methanol, gradient), to afford the product as an orange wax $(3.291 \mathrm{~g}, 91 \%)$, and used for further reactions. FT-IR (NaCl), $\bar{v}_{\max }: 2871$ (s, C-H st), 2104 (w, $\left.\mathrm{N}_{3} \mathrm{st}\right)$ $1761(\mathrm{~s}, \mathrm{C}=\mathrm{O} \mathrm{st}) \mathrm{cm}^{-1} ; \mathrm{UV}(\mathrm{DCM}) \lambda_{\max }=284 \mathrm{~nm} ; \mathrm{Em}(\mathrm{DCM}) \lambda_{\max }=412.5 \mathrm{~nm}(\lambda$ exc $=320 \mathrm{~nm}) ;{ }^{1} \mathrm{H}$ NMR (400 MHz, CDCl $)$ ) 8.57 (s, 1H, H-4), 7.79-7.56 (m, 2H, H-5 and H-7), 7.46-7.31 (m, 2H, H-6 and H-8), 4.58-4.41 (m, 2H, O- $\left.\mathrm{CH}_{2}-\mathrm{CH}_{2}-\mathrm{PEG}\right), 4.02-3.33$ (m, 90H, PEG); ${ }^{13} \mathrm{C} \mathrm{NMR}\left(101 \mathrm{MHz}, \mathrm{CDCl}_{3}\right)$

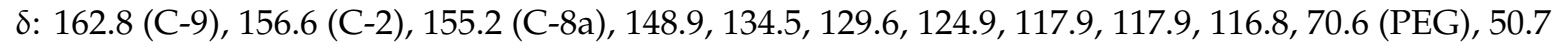
$\left(\mathrm{CH}_{2} \mathrm{~N}_{3}\right)$.

3.3.20. $\alpha$-Coumarin 3-Carboxylate- $\omega$-[(1H-1,2,3-triazol-4-yl)methoxygalactopyranosyl] PEG $_{1000}$ (20)

Azide polymer $19(0.500 \mathrm{~g}, 0.4 \mathrm{mmol})$ was dissolved in THF $(4.2 \mathrm{~mL})$ then copper iodide ( $0.039 \mathrm{~g}, 0.2 \mathrm{mmol})$, DIPEA $(0.14 \mathrm{~mL}, 0.8 \mathrm{mmol})$ and compound $10(0.086 \mathrm{~g}, 0.4 \mathrm{mmol})$ were added. The mixture was magnetically stirred under an argon atmosphere for $34 \mathrm{~h}$. After removal of the solvent under reduced pressure, the residue was suspended in DCM and washed twice with water, once with brine, dried over anhydrous sodium sulfate, filtered and concentrated. Purification by preparative chromatography (95:5 chloroform/methanol) afforded $\mathbf{2 0}$ as a yellow wax in $18 \%$ yield (0.105 g, $0.1 \mathrm{mmol})$. FT-IR (NaCl), $\bar{v}_{\max }: 3458$ (O-H st), 2876 (C-H st), 1759 (C=O st) cm ${ }^{-1}$. UV (DCM) $\lambda_{\max }=293 \mathrm{~nm} ; \mathrm{Em}(\mathrm{DCM}) \lambda_{\max }=413 \mathrm{~nm}(\lambda \mathrm{exc}=320 \mathrm{~nm}) ;{ }^{1} \mathrm{H} \mathrm{NMR}\left(400 \mathrm{MHz}, \mathrm{CDCl}_{3}\right) \delta: 8.57(\mathrm{~s}, 1 \mathrm{H}$, H-4), 8.23-7.99 (m, 1H, H-9'), 7.72-7.61 (m, 2H, H-5 and H-7), 7.40-7.32 (m, 2H, H-6 and H-8), 5.05 (s, 1H, H-1'), 4.87 (s, 1H, H-6a'), 4.74 (s, 1H (H-6b'), 4.62 (s, 2H, H-3'), 4.50 (s, 2H, H-7'), 4.30-3.34 (m, 100H, PEG); ${ }^{13} \mathrm{C}$ NMR (101 MHz, $\mathrm{CDCl}_{3}$ ) $\delta:$ 162.8, 156.6, 155.2, 149.2 (C-4), 148.9, 134.5 (C-7), 129.6 (C-5), 124.9 (C-9' and C-6), 117.9, 117.9, 116.8 (C-8), 98.8 (C-1'), 70.5 (PEG), 69.9 (C-2'), 69.0 (C-4'), 68.9 (PEG), 64.9 (C-7'), 62.1, 60.3 (C-6'), 52.9, 51.1 (C-3').

\subsubsection{1. $\alpha$-Tosyl- $\omega$-Tosyl $\mathrm{PEG}_{1000}$ (21)}

PEG (5.000 g, $5 \mathrm{mmol})$ was dissolved in DCM $(50 \mathrm{~mL})$ with magnetic stirring and an argon atmosphere. Triethylamine $(1.6 \mathrm{~mL}, 11.0 \mathrm{mmol})$ and tosyl chloride $(2.383,12.5 \mathrm{mmol})$ were added and the reaction mixture was heated at $50{ }^{\circ} \mathrm{C}$ for $15 \mathrm{~h}$. The mixture was concentrated under vacuum and purified by column chromatography (chloroform to 9:1 chloroform/methanol gradient) affording quantitatively the product $21(6.542 \mathrm{~g}, 100 \%)$ as a yellowish wax. FT-IR $(\mathrm{NaCl}), \bar{v}_{\text {max }}: 3511$ (br, O-H st), 2873 (s, C-H st) cm ${ }^{-1} ;{ }^{1} \mathrm{H}$ NMR $\left(400 \mathrm{MHz}, \mathrm{CDCl}_{3}\right) \delta: 7.80(\mathrm{~d}, J=6.7 \mathrm{~Hz}, 4 \mathrm{H}, \mathrm{H}-\mathrm{Ar}), 7.35$ (d, J = $6.4 \mathrm{~Hz}$, $4 \mathrm{H}, \mathrm{H}-\mathrm{Ar}$ ), 4.16 (s, 4H, 2x $\left.\underline{\mathrm{C}}_{2}-\mathrm{OTs}\right), 3.75-3.49$ (m, 89H, PEG), 3.38 (s, 2H, PEG), 2.45 (s, 6H, 2x CH CH$_{3}$; ${ }^{13} \mathrm{C}$ NMR (101 MHz, CDCl 3 ) 8: 144.8 (C-Ar), 133.1 (C-Ar), 129.8 (C-Ar), 128.0 (C-Ar), 70.8 (PEG), 70.6 (PEG), 70.6 (PEG), 69.3 (PEG), 68.7 (PEG), $21.6\left(\mathrm{CH}_{3}\right)$.

\subsubsection{2. $\alpha$-Azide- $\omega$-Azide PEG $_{1000}$ (22)}

To a solution of compound 21 (1.488 g, $1.1 \mathrm{mmol})$ in DMF $(18 \mathrm{~mL})$ under magnetic stirring and argon atmosphere was added sodium azide $(0.222 \mathrm{~g}, 3.4 \mathrm{mmol})$ and the reaction was heated at $50{ }^{\circ} \mathrm{C}$ for $16 \mathrm{~h}$. The solvent was evaporated under reduced pressure and then dichloromethane $(35 \mathrm{~mL})$ was added and the organic phase was washed twice with brine $(2 \times 20 \mathrm{~mL})$ and once with water $(20 \mathrm{~mL})$, dried over anhydrous sodium sulfate, filtered, concentrated, and purified by column chromatography (chloroform to 9:1 chloroform/methanol stepwise) affording product $22(0.966 \mathrm{~g}$, $0.9 \mathrm{mmol})$ as a yellowish wax; ${ }^{1} \mathrm{H} \mathrm{NMR}\left(400 \mathrm{MHz}, \mathrm{CDCl}_{3}\right) \delta: 3.65(\mathrm{~s}, 90 \mathrm{H}, \mathrm{PEG}), 3.39(\mathrm{t}, J=4.5 \mathrm{~Hz}, 4 \mathrm{H}$, $\left.2 \times \mathrm{CH}_{2}-\mathrm{N}_{3}\right) ;{ }^{13} \mathrm{C} \mathrm{NMR}\left(101 \mathrm{MHz}, \mathrm{CDCl}_{3}\right)$ 8: 70.7 (PEG), 70.7 (PEG), 70.6 (PEG), 70.6 (PEG), 70.0 (PEG), $50.7\left(2 \times \mathrm{CH}_{2} \mathrm{~N}_{3}\right)$.

\subsubsection{3. $\alpha$-Azide- $\omega$-[7-((1H-1,2,3-Triazol-4-yl)methoxy)-2H-Chromen-2-One)] PEG $_{1000}$ (23)}

Compounds $22(0.966 \mathrm{~g}, 0.9 \mathrm{mmol})$ and $4(0.184 \mathrm{~g}, 0.9 \mathrm{mmol})$, copper iodide $(0.101 \mathrm{~g}, 0.5 \mathrm{mmol})$, and DIPEA $(0.32 \mathrm{~mL}, 1.8 \mathrm{mmol})$ were mixed in THF $(8 \mathrm{~mL})$ under magnetic stirring and an argon atmosphere for $18 \mathrm{~h}$. The solvent was evaporated under reduced pressure and then dichloromethane 
(35 mL) was added. The resulting organic phase was washed three times with water $(3 \times 20 \mathrm{~mL})$, dried over anhydrous sodium sulfate, filtered, concentrated, and purified by column chromatography (chloroform to 9:1 chloroform/methanol, gradient) affording product $23(0.947 \mathrm{~g}, 82 \%)$ as an orange wax. FT-IR (NaCl) $\bar{v}_{\max }: 3553$ (w, O-H st) 2872 (s, C-H st), 2106 (w, N $\mathrm{N}_{3}$ st), 1732 (s, C=O), 1614 (s, C=C bend) $\mathrm{cm}^{-1} ; \mathrm{UV}(\mathrm{DCM}) \lambda_{\max }=322 \mathrm{~nm}$; Em $(\mathrm{DCM}) \lambda_{\max }=386 \mathrm{~nm}(\lambda$ exc $=320 \mathrm{~nm}) ;{ }^{1} \mathrm{H} \mathrm{NMR}(400 \mathrm{MHz}$, $\left.\mathrm{CDCl}_{3}\right) \delta: 8.00\left(\mathrm{~s}, 1 \mathrm{H}, \mathrm{H}-8^{\prime}\right), 7.66\left(\mathrm{~d}, J=9.5 \mathrm{~Hz}, 1 \mathrm{H}, \mathrm{H}-6^{\prime}\right), 7.41\left(\mathrm{~d}, J=8.4 \mathrm{~Hz}, 1 \mathrm{H}, \mathrm{H}-4^{\prime}\right), 7.03-6.88(\mathrm{~m}$, 2H, H-3' and H-5), $6.26\left(\mathrm{~d}, J=9.5 \mathrm{~Hz}, 1 \mathrm{H}, \mathrm{H}-5^{\prime}\right), 5.29(\mathrm{~s}, 2 \mathrm{H}, \mathrm{H}-6), 4.60(\mathrm{t}, J=4.2 \mathrm{~Hz}, 2 \mathrm{H}, \mathrm{PEG}), 3.90(\mathrm{t}$, $J=4.6 \mathrm{~Hz}, 4 \mathrm{H}, \mathrm{PEG}), 3.82-3.54(\mathrm{~m}, 82 \mathrm{H}, \mathrm{PEG}), 3.39\left(\mathrm{t}, J=4.8 \mathrm{~Hz}, 2 \mathrm{H}, \mathrm{N}_{3}-\mathrm{CH}_{2}\right) ;{ }^{13} \mathrm{C} \mathrm{NMR}(101 \mathrm{MHz}$, $\left.\mathrm{CDCl}_{3}\right)$ 8: $161.4\left(\mathrm{C}-2^{\prime}\right), 161.0\left(\mathrm{C}-7^{\prime}\right), 155.7\left(\mathrm{C}-8 \mathrm{a}^{\prime}\right), 143.4(\mathrm{C}-4), 142.4\left(\mathrm{C}-6^{\prime}\right), 129.0\left(\mathrm{C}-4^{\prime}\right), 124.8\left(\mathrm{C}-8^{\prime}\right), 113.4$ (C-5'), 113.0 (C-4a'), 112.8 (C-5), 102.1 (C-3'), 70.7 (PEG), 70.6 (PEG), 70.5 (PEG), 70.4 (PEG), 70.3 (PEG), 70.0 (PEG), 69.3 (PEG), 62.1 (C-6), $50.7\left(2 \times \mathrm{CH}_{2}-\mathrm{N}_{3}\right)$.

3.3.24. $\alpha-[7-((1 H-1,2,3-$ triazol-4-yl)methoxy)-2H-Chromen-2-One)]- $\omega-[(1 H-1,2,3-$ triazol-4-yl) methoxygalactopyranosyl] PEG 1000 (24)

Azide $4(0.150 \mathrm{~g}, 0.1 \mathrm{~mol})$, propargylated galactopyranosyl 10 (0.039 g, $0.2 \mathrm{mmol})$, copper iodide $(0.011 \mathrm{~g}, 0.06 \mathrm{mmol})$, DIPEA $(0.04 \mathrm{~mL}, 0.2 \mathrm{mmol})$, and 2,2'-bipyridine $(0.009 \mathrm{~g}, 0.06 \mathrm{mmol})$ were dissolved in THF $(1 \mathrm{~mL})$, and mixed together under magnetic stirring and argon atmosphere for $22 \mathrm{~h}$. The mixture was evaporated under reduced pressure, and the residue was dissolved in chloroform $(10 \mathrm{~mL})$, washed two times with deionized water $(10 \mathrm{~mL})$, once with brine $(10 \mathrm{~mL})$, dried over anhydrous sodium sulfate, filtered, concentrated, and purified by column chromatography (chloroform to 9:1 chloroform/methanol, stepwise) to afford $24(0.019 \mathrm{~g}, 11 \%)$ as an orange wax. $\lambda \mathrm{Abs}_{\max }=321 \mathrm{~nm}$; $\lambda \mathrm{Em}_{\max }=383.5 \mathrm{~nm}\left(\lambda_{\mathrm{exc}}=320 \mathrm{~nm}\right) ;{ }^{1} \mathrm{H} \mathrm{NMR}\left(400 \mathrm{MHz}, \mathrm{CDCl}_{3}\right) \delta: 7.93(\mathrm{~s}, 2 \mathrm{H}, \mathrm{H}-11$ and H-12), 7.66 $(\mathrm{d}, J=9.4 \mathrm{~Hz}, 1 \mathrm{H}, \mathrm{H}-4), 7.40(\mathrm{~d}, J=9.3 \mathrm{~Hz}, 1 \mathrm{H}, \mathrm{H}-5), 7.02-6.91(\mathrm{~m}, 2 \mathrm{H}, \mathrm{H}-6$ and H-8), 6.27 (d, J = 9.4 Hz, $1 \mathrm{H}, \mathrm{H}-3), 5.32-5.24$ (m, 2H, H-9), 5.10-5.00 (m, 2H, H-1'), 4.93-4.66 (m, 3H), 4.65-4.47 (m, 4H, H-14), 4.47-4.20 (m, 2H), 4.19-3.99 (m, 3H), 3.95-3.78 (m, 10H, PEG), 3.78-3.39 (m, 120H, PEG), 3.24-3.05 (m, 6H, PEG); ${ }^{13} \mathrm{C}$ NMR (101 MHz, CDCl 3 ) $\delta: 161.4$ (C-2), 161.1 (C-7), 155.7 (C-8a), 143.4 (C-4), 142.6 (C-10 and C-13), 128.9 (C-5), 124.6 (C-11 and C-12), 113.3 (C-13), 112.9 (C-4a), 112.8 (C-6), 102.1 (C-8), 72.7 (PEG), 70.5 (PEG), 69.3 (PEG), 62.3 (C-9), 61.6 (PEG), 50.4 (C-14).

3.3.25. $\alpha-[7-((1 H-1,2,3-T r i a z o l-4-y l) m e t h o x y)-2 H-C h r o m e n-2-O n e)]-\omega-[(1 H-1,2,3-t r i a z o l-4-y l)$ methoxymannopyranosyl] PEG $_{1000}$ (25)

Azide 4 (0.153 g, $0.1 \mathrm{~mol})$, propargylated mannopyranosyl 11 (0.055 g, $0.3 \mathrm{mmol})$, copper iodide (0.033 g, $0.18 \mathrm{mmol})$, DIPEA $(0.04 \mathrm{~mL}, 0.2 \mathrm{mmol})$ and 2,2'-bipyridine (0.013 g, $0.08 \mathrm{mmol})$ were dissolved in THF $(1 \mathrm{~mL})$, and mixed together under magnetic stirring and argon atmosphere for $22 \mathrm{~h}$. The mixture was evaporated under reduced pressure, and the residue was dissolved in chloroform $(10 \mathrm{~mL})$, washed two times with deionized water $(10 \mathrm{~mL})$, once with brine $(10 \mathrm{~mL})$, dried over anhydrous sodium sulfate, filtered, concentrated, and purified by column chromatography (chloroform to 9:1 chloroform/methanol, stepwise) to afford $25(0.030 \mathrm{~g}, 17 \%)$ as an orange wax. $\lambda \mathrm{Abs}_{\max }=321$ $\mathrm{nm} ; \lambda \mathrm{Em}_{\max }=386.5 \mathrm{~nm}\left(\lambda_{\mathrm{exc}}=320 \mathrm{~nm}\right) ;{ }^{1} \mathrm{H} \mathrm{NMR}\left(400 \mathrm{MHz}, \mathrm{CDCl}_{3}\right) \delta: 8.01-7.81(\mathrm{~m}, 2 \mathrm{H}, \mathrm{H}-11$ and H-12), $7.66(\mathrm{~d}, J=9.5 \mathrm{~Hz}, 1 \mathrm{H}, \mathrm{H}-4), 7.41(\mathrm{~d}, J=8.8 \mathrm{~Hz}, 1 \mathrm{H}, \mathrm{H}-5), 7.05-6.88(\mathrm{~m}, 2 \mathrm{H}, \mathrm{H}-6$ and H-8), 6.27 $(\mathrm{d}, J=9.4 \mathrm{~Hz}, 1 \mathrm{H}, \mathrm{H}-3), 5.35-5.22(\mathrm{~m}, 2 \mathrm{H}, \mathrm{H}-9), 5.11-4.90\left(\mathrm{~m}, 2 \mathrm{H}, \mathrm{H}-\mathrm{1}^{\prime}\right), 4.85-4.64(\mathrm{~m}, 3 \mathrm{H}), 4.63-4.48$ (m, 5H, H-14), 4.31-2.97 (m, 140H, PEG); $\left.{ }^{13} \mathrm{C} \mathrm{NMR} \mathrm{(101} \mathrm{MHz,} \mathrm{CDCl}\right)$ ) : 161.4 (C-2), 161.1 (C-7), 155.7 (C-8a), 143.4 (C-4), 142.7 (C-10 and C-13), 129.0 (C-5), 124.6 (C-11 and C-12), 113.4 (C-3), 112.9 (C-4a), 112.9 (C-6), 102.1 (C-8), 72.7 (PEG), 70.5 (PEG), 69.4 (PEG), 69.0 (PEG), 62.3 (C-9), 50.4 (C-14).

3.3.26. $\alpha$-3-[3-(4,8-Dimethyl]-7-(2-Propynyloxy)]-Coumarinyl Propanoate- $\omega-3-[3-(4,8-d i m e t h y l]-7-$ (2-propynyloxy)]-coumarinyl propanoate $\mathrm{PEG}_{1000}$ (26)

Compound 3 (0.099 g, $0.3 \mathrm{mmol})$, DMAP $(0.004 \mathrm{~g}, 0.03 \mathrm{mmol})$ and coupling agent DCC (0.075 $\mathrm{g}, 0.4 \mathrm{mmol})$ were stirred in DCM $(7 \mathrm{~mL})$ for $30 \mathrm{~min}$. Then, PEG $(0.150 \mathrm{~g}, 0.15 \mathrm{mmol})$ was added. After $16 \mathrm{~h}, \mathrm{DCM}(10 \mathrm{~mL})$ and acetic acid solution $(0.25 \mathrm{M}, 10 \mathrm{~mL})$ were added to the reaction mixture. 
After $1 \mathrm{~h}$ the organic phase was separated and washed with deionized water $(2 \times 10 \mathrm{~mL})$, dried over anhydrous sodium sulfate, filtered, evaporated and purified by silica gel column chromatography using chloroform/methanol 9:1, affording $26(0.170 \mathrm{~g}, 74 \%)$ as a yellow wax. FT-IR $(\mathrm{NaCl}) \bar{v}_{\text {max }}: 3259$ (s, =C-H w), 3008 (s, C-H w), 2929 (s, C-H w), 1733 (s), 1701 (s, O-C=O st) cm ${ }^{-1}$; ${ }^{1} \mathrm{H} \mathrm{NMR}(400 \mathrm{MHz}$, $\left.\mathrm{CDCl}_{3}\right)$ \&: $7.47(\mathrm{~d}, J=8.9 \mathrm{~Hz}, 2 \mathrm{H}, \mathrm{H}-5), 6.98(\mathrm{~d}, J=8.9 \mathrm{~Hz}, 2 \mathrm{H}, \mathrm{H}-6), 4.82\left(\mathrm{~d}, J=2.2 \mathrm{~Hz}, 4 \mathrm{H}, \mathrm{H}-1^{\prime}\right), 4.23$ $(\mathrm{t}, J=4.6 \mathrm{~Hz}, 4 \mathrm{H}, \mathrm{H}-16), 3.66\left(\mathrm{~s}, 82 \mathrm{H}, \mathrm{CH}_{2}-\mathrm{PEG}\right), 2.98(\mathrm{t}, J=7.6 \mathrm{~Hz}, 4 \mathrm{H}, \mathrm{H}-13), 2.66(\mathrm{t}, J=7.6 \mathrm{~Hz}, 4 \mathrm{H}$, $\mathrm{H}-14), 2.57\left(\mathrm{t}, J=2.0 \mathrm{~Hz}, 2 \mathrm{H}, \mathrm{H}-3^{\prime}\right), 2.45(\mathrm{~s}, 3 \mathrm{H}, \mathrm{H}-12), 2.34(\mathrm{~s}, 3 \mathrm{H}, \mathrm{H}-11) ;{ }^{13} \mathrm{C}$ NMR $\left(101 \mathrm{MHz}, \mathrm{CDCl}_{3}\right)$ ঠ: 172.9 (C-15), 161.7 (C-2), 157.4(C-7), 151.4 (C-9), 147.5 (C-4), 122.5 (C-5), 121.7 (C-3), 115.0 (C-10), 114.7(C-8), 108.3 (C-6), 78.2 (C-2'), 77.3 (C-3'), 70.6 ( $\mathrm{CH}_{2}$-PEG), 63.7 (C-16), 56.4 (C-1'), 32.6 (C-14), 23.1 (C-13), 15.0 (C-12), 8.3 (C-11).

3.3.27. $\alpha$-Thymidinyl-5-((1,2,3-Triazol-1-yl)-3-[3-(4,8-Dimethyl)-7-(Methyloxi)-Cumarinyl) propanoate- $\omega$ - Thymidinyl-5-((1,2,3-Triazol-1-yl)-3-[3-(4,8-Dimethyl)-7-(Methyloxi)-Cumarinyl) propanoate $\mathrm{PEG}_{1000}(27)$

Compound 26 (0.060 g, $0.04 \mathrm{mmol})$, DIPEA $(0.2 \mathrm{~mL}, \mathrm{mmol})$, copper iodide $(0.008 \mathrm{~g}$, cat. $)$ and compound $16(0.499 \mathrm{~g}, 1.3 \mathrm{mmol})$ were stirred in THF $(4.0 \mathrm{~mL})$ for $3 \mathrm{~h}$. After solvent evaporation the mixture was dissolved in dichloromethane and purified by column chromatography using hexane/ethyl acetate (1:1) as eluent, affording $27(0.070 \mathrm{~g}, 87 \%)$ as a yellow wax. ${ }^{1} \mathrm{H}-\mathrm{NMR}\left(\mathrm{CDCl}_{3}, 400 \mathrm{MHz}\right) \delta: 7.77$ $\left(\mathrm{d}, J=9.6 \mathrm{~Hz}, 2 \mathrm{H}, \mathrm{H}-5^{\prime}\right), 7.41(\mathrm{~d}, J=8.8 \mathrm{~Hz}, 2 \mathrm{H}, \mathrm{H}-5), 7.30$ (s, 2H, H-6"), 6.98 (d, J = 8.7 Hz, 2H, H-6), $6.24\left(\mathrm{t}, J=6.8 \mathrm{~Hz}, 2 \mathrm{H}, \mathrm{H}-1^{\prime \prime}\right), 4.70\left(\mathrm{dd}, J=15.2,10.0 \mathrm{~Hz}, 4 \mathrm{H}, \mathrm{H}-6^{\prime}\right), 4.47\left(\mathrm{~m}, 2 \mathrm{H}, \mathrm{H}-3^{\prime \prime}\right), 4.20(\mathrm{t}, J=5.1 \mathrm{~Hz}$, $4 \mathrm{H}, \mathrm{H}-16,), 4.02\left(\mathrm{q}, J=3.9 \mathrm{~Hz}, 2 \mathrm{H}, \mathrm{H}-4^{\prime \prime}\right), 3.60$ (s, J = 12.8 Hz, 100H, H-PEG, 5"), 2.95 (t, $J=7,1 \mathrm{~Hz}, 4 \mathrm{H}$, $\mathrm{H}-13), 2.62(\mathrm{t}, J=7.0 \mathrm{~Hz}, 4 \mathrm{H}, \mathrm{H}-14), 2.40-2.25$ (m, 16H, H-11,12, 2"), 1.92-1.86 (m, 6H, H-8"); ${ }^{13} \mathrm{C}-\mathrm{NMR}$ $\left(\mathrm{CDCl}_{3}, 100 \mathrm{MHz}\right)$ 8: 172.9 (C-15), 163.8 (C-9"), 161.9 (C-2), 158.1 (C-7), 151,3 (C-9), 150.4 (C-10"), 147.9 (C-4), 143.8 (C-4'), 135.5 (C-5'), 124.8 (C-6"), 122.8 (C-6), 121.3 (C-3), 114.7 (C-10), 114.1 (C-8), 111.4 (C-7"), 108.3 (C-5), 84.9 (C-1"), 84.5 (C-4"), 71.5 (C-3"), 71.2 (C-3"), 70.5 (C-PEG), 63.7 (C-16), 52.3 (C-5"), 51.3 (C-6'), 40.2 (C-2"), 32.6 (C-14), 23.1 (C-13), 15.0 (C-12), 12.6 (C-8"), 12.4 (C-8"), 8.3 (C-11).

\subsubsection{1-[1'-Ethylamide-Triazolyl-4]-1-O-Methyl-D-Glucopyranoside-PLGA Conjugate (28)}

Compound $14(0.006 \mathrm{~g}, 0.02 \mathrm{mmol})$ was dissolved in $4 \mathrm{~mL}$ of DMF, and commercially available polymer poly(D,L-lactide-co-glycolide) $(0.200 \mathrm{~g}, 0.02 \mathrm{mmol})$ was added. To the stirred reaction mixture, methanesulfonic acid $(0.5 \mathrm{~mL}, 7.70 \mathrm{mmol})$ was added and the reaction proceeded overnight at $65^{\circ} \mathrm{C}$. The solution was cooled down, and $4 \mathrm{~mL}$ of cold water was added. The precipitated polymer was collected by filtration to give the PLGA derivative $28(0.193 \mathrm{~g}, 100 \%)$ as a white solid.

3.3.29. 7-((1-(2-Amide-Ethyl)-1H-1,2,3-Triazol-4-yl)methoxy)-4-Methyl-2H-Chromen-2-One-PLGA Conjugate (29)

Compound 8 ( $0.006 \mathrm{~g}, 0.02 \mathrm{mmol})$ was dissolved in $4 \mathrm{~mL}$ of DMF, and poly(D,L-lactide-co-glycolide) $(0.200 \mathrm{~g}, 0.02 \mathrm{mmol})$ was added and this mixture stirred at room temperature. Methanesulfonic acid $(0.5 \mathrm{~mL}, 7.70 \mathrm{mmol})$ was added, and heated overnight at $65^{\circ} \mathrm{C}$. The solution was cooled and $4 \mathrm{~mL}$ of cold water was added. The precipitated polymer was collected by filtration to give the PLGA derivative $29(0.197 \mathrm{~g}, 100 \%)$ as a white solid.

\section{Conclusions}

The use of these two polymeric building blocks (PEG and PLGA) has allowed us to prepare a new type of macromolecule functionalized with carbohydrate and coumarin moieties. The polymer PEG was selectively functionalized making possible the production of asymmetric macromolecules that contain at one terminal the carbohydrate unit and at the other the coumarin molecule. This asymmetry provides the ability to obtain a self-assembling control during the nanoparticles oil in water transformation. This kind of macromolecules showed a tendency to form aggregates with sizes ranging between 220 and $580 \mathrm{~nm}$, respectively, but the majority of the sample presented a polymeric film after the medium 
evaporation. This film formation can suggest that the hydrophobic core is not big enough to provide the desired self-assembling effect.

PLGA has been successfully functionalized and transformed into stable and spherical nanoparticles with a smooth surface, with practically no aggregation. The size of these different particles ranges between $114-289 \mathrm{~nm}$ with a zeta potential value of $-28.2 \mathrm{mV}$ for the glucoconjugate and $-56.0 \mathrm{mV}$ for the coumarin-containing derivative. Using a single oil in water emulsion technique, it was possible to obtain low polydispersity indexes for all PLGA nanoparticles.

Supplementary Materials: The following are available online at http://www.mdpi.com/1420-3049/25/7/1744/s1, Figures S1-S51: ${ }^{1} \mathrm{H},{ }^{13} \mathrm{C}$ and MS/MALDI spectra of synthesized compounds.

Author Contributions: Conceptualization, C.D.R., C.A.C., and M.T.B.; methodology, C.D.R., C.A.C., and M.T.B.; investigation, C.D.R. and C.A.C.; resources, M.T.B..; data curation, C.D.R. and C.A.C.; writing-original draft preparation, C.D.R.; writing-review and editing, C.A.C. and M.T.B..; visualization, C.D.R.; supervision, M.T.B.; project administration, M.T.B.; funding acquisition, M.T.B. All authors have read and agreed to the published version of the manuscript.

Funding: This research was funded by Fundação para a Ciência e a Tecnologia, grant number PD/BD/109680/2015. This work was also supported by the Associate Laboratory for Green Chemistry, LAQV, which is financed by national funds from FCT/MEC (UID/QUI/50006/2013 and UID/QUI/50006/2019) and co-financed by the ERDF under the PT2020 Partnership Agreement (POCI-01-0145-FEDER-007265).

Acknowledgments: The authors acknowledge the help of Christopher D. Maycock for useful suggestions and Carlos Lodeiro and José Luis Capelo (Bioscope) for the opportunity to share this work in their conferences and meetings.

Conflicts of Interest: The authors declare no conflict of interest.

\section{References}

1. Hulla, J.E.; Sahu, S.C.; Hayes, A.W. Nanotechnology: History and future. Hum. Exp. Toxicol. 2015, 34, 1318-1321. [CrossRef] [PubMed]

2. Feynman, R.P. There's Plenty of Room at the Bootom.pdf. J. Microelectromechanical Syst. 1992, 1, 60-66. [CrossRef]

3. Shi, J.; Votruba, A.R.; Farokhzad, O.C.; Langer, R. Nanotechnology in drug delivery and tissue engineering: From discovery to applications. Nano Lett. 2010, 10, 3223-3230. [CrossRef] [PubMed]

4. Niska, K.; Zielinska, E.; Radomski, M.W.; Inkielewicz-Stepniak, I. Metal nanoparticles in dermatology and cosmetology: Interactions with human skin cells. Chem. Biol. Interact. 2018, 295, 38-51. [CrossRef] [PubMed]

5. Kreuter, J. Nanoparticles-a historical perspective. Int. J. Pharm. 2007, 331, 1-10. [CrossRef] [PubMed]

6. Langer, R. Drug delivery and targeting. Nature 1998, 392, 5-10.

7. Nahar, M.N.S.; Dutta, T.; Murugesan, S.; Asthana, A.; Kumar, D.M.; Rajkumar, V.; Tare, M.; Pachouri, R.; Jain, N.K. Functional polymeric nanoparticles: An efficient and promising tool for active delivery of bioactives. Crit. Rev. Ther. Drug Carrier Syst. 2006, 23, 259-318. [CrossRef]

8. Mc Carthy, D.J.; Malhotra, M.; O'Mahony, A.M.; Cryan, J.F.; O’Driscoll, C.M. Nanoparticles and the blood-brain barrier: Advancing from in-vitro models towards therapeutic significance. Pharm. Res. 2015, 32, 1161-1185. [CrossRef]

9. BaoLin, G.; MA, P.X. Synthetic biodegradable functional polymers for tissue engineering: A brief review. Sci. China Chem. 2014, 57, 490-500.

10. Bhatia, S. Natural Polymer Drug Delivery Systems: Nanoparticles, Plants and Algae; Springer Int. Publishing: Basel, Switzerland, 2016; ISBN 9783319411286.

11. Longmire, M.; Choyke, P.L.; Kobayashi, H. Clearance properties of nano-sized particles and molecules as imaging agents: Considerations and caveats. Nanomedicine 2008, 3, 703-717. [CrossRef]

12. Caldorera-Moore, M.; Guimard, N.; Shi, L.; Roy, K. Designer nanoparticles: Incorporating size, shape and triggered release into nanoscale drug carriers. Expert Opin. Drug Deliv. 2010, 7, 479-495. [CrossRef] [PubMed]

13. Ilium, L.; Davis, S.S.; Wilson, C.G.; Thomas, N.W.; Frier, M.; Hardy, J.G. Blood clearance and organ deposition of intravenously administered colloidal particles. The effects of particle size, nature and shape. Int. J. Pharm. 1982, 12, 135-146. [CrossRef] 
14. Panyam, J.; Dali, M.M.; Sahoo, S.K.; Ma, W.; Chakravarthi, S.S.; Amidon, G.L.; Levy, R.J.; Labhasetwar, V. Polymer Degradation and in vitro release of a model protein from poly(D,L-lactide-co-glycolide) nano- and microparticles. J. Control. Release 2003, 92, 173-187. [CrossRef]

15. Yoo, J.W.; Doshi, N.; Mitragotri, S. Adaptive micro and nanoparticles: Temporal control over carrier properties to facilitate drug delivery. Adv. Drug Deliv. Rev. 2011, 63, 1247-1256. [CrossRef]

16. Champion, J.A.; Katare, Y.K.; Mitragotri, S. Particle shape: A new design parameter for micro- and nanoscale drug delivery carriers. J. Control. Release 2007, 121, 3-9. [CrossRef]

17. Yamamoto, Y.; Nagasaki, Y.; Kato, Y.; Sugiyama, Y.; Kataoka, K. Long-circulating poly(ethylene glycol)-poly(D,L-lactide) block copolymer micelles with modulated surface charge. J. Control. Release 2001, 77, 27-38. [CrossRef]

18. Wang, A.; Pu, K.; Dong, B.; Liu, Y.; Zhang, L.; Zhang, Z.; Duan, W.; Zhu, Y. Role of surface charge and oxidative stress in cytotoxicity and genotoxicity of graphene oxide towards human lung fibroblast cells. J. Appl. Toxicol. 2013, 33, 1156-1164. [CrossRef]

19. Alexis, F.; Pridgen, E.; Molnar, L.K.; Farokhzad, O.C. Factors affecting the clearance and biodistribution of polymeric nanoparticles. Mol. Pharm. 2008, 5, 505-515. [CrossRef]

20. Chung, T.H.; Wu, S.H.; Yao, M.; Lu, C.W.; Lin, Y.S.; Hung, Y.; Mou, C.Y.; Chen, Y.C.; Huang, D.M. The effect of surface charge on the uptake and biological function of mesoporous silica nanoparticles in 3T3-L1 cells and human mesenchymal stem cells. Biomaterials 2007, 28, 2959-2966. [CrossRef]

21. Ahmed, M.; Narain, R. Carbohydrate-based materials for targeted delivery of drugs and genes to the liver. Nanomedicine 2015, 10, 2263-2288. [CrossRef]

22. Alexis, F.; Rhee, J.W.; Richie, J.P.; Radovic-Moreno, A.F.; Langer, R.; Farokhzad, O.C. New frontiers in nanotechnology for cancer treatment. Urol. Oncol. Semin. Orig. Investig. 2008, 26, 74-85. [CrossRef] [PubMed]

23. Shokoohinia, Y.; Sajjadi, S.E.; Gholamzadeh, S.; Fattahi, A.; Behbahani, M. Antiviral and cytotoxic evaluation of coumarins from Prangos ferulacea. Pharm. Biol. 2014, 52, 1543-1549. [CrossRef] [PubMed]

24. Shaikh, M.H.; Subhedar, D.D.; Shingate, B.B.; Kalam Khan, F.A.; Sangshetti, J.N.; Khedkar, V.M.; Nawale, L.; Sarkar, D.; Navale, G.R.; Shinde, S.S. Synthesis, biological evaluation and molecular docking of novel coumarin incorporated triazoles as antitubercular, antioxidant and antimicrobial agents. Med. Chem. Res. 2016, 25, 790-804. [CrossRef]

25. Gurrapu, S.; Jonnalagadda, S.K.; Alam, M.A.; Ronayne, C.T.; Nelson, G.L.; Solano, L.N.; Lueth, E.A.; Drewes, L.R.; Mereddy, V.R. Coumarin carboxylic acids as monocarboxylate transporter 1 inhibitors: In vitro and in vivo studies as potential anticancer agents. Bioorg. Med. Chem. Lett. 2016, 26, 3282-3286. [CrossRef] [PubMed]

26. Dawood, D.H.; Batran, R.Z.; Farghaly, T.A.; Khedr, M.A.; Abdulla, M.M. New Coumarin Derivatives as Potent Selective COX-2 Inhibitors: Synthesis, Anti-Inflammatory, QSAR, and Molecular Modeling Studies. Arch. Pharm. (Weinheim) 2015, 348, 875-888. [CrossRef]

27. Kolb, H.C.; Sharpless, K.B. The growing impact of click chemistry on drug discovery. Drug Discov. Today 2003, 8, 1128-1137. [CrossRef]

28. Arslan, M.; Acik, G.; Tasdelen, M.A. The emerging applications of click chemistry reactions in the modification of industrial polymers. Polym. Chem. 2019, 10, 3806-3821. [CrossRef]

29. Zou, Y.; Zhang, L.; Yang, L.; Zhu, F.; Ding, M.; Lin, F.; Wang, Z.; Li, Y. “Click” chemistry in polymeric scaffolds: Bioactive materials for tissue engineering. J. Control. Release 2018, 273, 160-179. [CrossRef]

30. Pechmann, H.V. Neue Bildungsweise der Cumarine. Synthese des Daphnetins. I. Ber. Dtsch. Chem. Ges. 1884, 17, 926-936. [CrossRef]

31. Knoevenagel, E. Condensation von Malonsäure mit aromatischen Aldehyden durch Ammoniak und Amine. Ber. Dtsch. Chem. Ges. 1898, 31, 2596-2619. [CrossRef]

32. Perkin, W.H. On the artificial production of coumarin and formation of its homologues. J. Chem. Soc. 1868, 21, 53-63. [CrossRef]

33. Fuson, R.C.; Thomas, N. Extension of the reformatsky reaction to new types of compounds. J. Org. Chem. 1953, 18, 1762-1766. [CrossRef]

34. Fan, G.J.; Mar, W.; Park, M.K.; Wook Choi, E.; Kim, K.; Kim, S. A novel class of inhibitors for steroid $5 \alpha$-Reductase: Synthesis and evaluation of umbelliferone derivatives. Bioorg. Med. Chem. Lett. 2001, 11, 2361-2363. [CrossRef] 
35. Pramitha, P.; Bahulayan, D. Stereoselective synthesis of bio-hybrid amphiphiles of coumarin derivatives by Ugi-Mannich triazole randomization using copper catalyzed alkyne azide click chemistry. Bioorg. Med. Chem. Lett. 2012, 22, 2598-2603. [CrossRef]

36. Roy, B.; Mukhopadhyay, B. Sulfuric acid immobilized on silica: An excellent catalyst for Fischer type glycosylation. Tetrahedron Lett. 2007, 48, 3783-3787. [CrossRef]

37. Salmaso, S.; Caliceti, P. Stealth Properties to Improve Therapeutic Efficacy of Drug Nanocarriers. J. Drug Deliv. 2013, 2013, 1-19. [CrossRef] [PubMed]

38. Anderson, J.M.; Kim, S.W. Recent Advances in Drug Delivery; Plenum Press: New York, NY, USA, 1984; ISBN 9781420008333.

39. Guo, F.; Fan, Z.; Yang, J.; Li, Y.; Wang, Y.; Zhao, H.; Xie, L.; Hou, Z. A Comparative Evaluation of Hydroxycamptothecin Drug Nanorods With and Without Methotrexate Prodrug Functionalization for Drug Delivery. Nanoscale Res. Lett. 2016, 11, 384. [CrossRef]

40. Wang, X.; Gu, X.; Wang, H.; Sun, Y.; Wu, H.; Mao, S. Synthesis, characterization and liver targeting evaluation of self-assembled hyaluronic acid nanoparticles functionalized with glycyrrhetinic acid. Eur. J. Pharm. Sci. 2017, 96, 255-262. [CrossRef]

41. Wang, Y.; Tian, Y.; Zhu, P.; Ma, Y.; He, J.; Lei, J. Self-assembled nanoparticles based on poly(ethylene glycol)-oleanolic acid conjugates for co-delivery of anticancer drugs. RSC Adv. 2017, 7, 29591-29598. [CrossRef]

42. Chan, T.R.; Hilgraf, R.; Sharpless, K.B.; Fokin, V.V. Polytriazoles as copper(I)-stabilizing ligands in catalysis. Org. Lett. 2004, 6, 2853-2855. [CrossRef]

43. Sharma, S.; Parmar, A.; Kori, S.; Sandhir, R. PLGA-based nanoparticles: A new paradigm in biomedical applications. TrAC-Trends Anal. Chem. 2016, 80, 30-40. [CrossRef]

44. Lü, J.-M.; Wang, X.; Marin-Muller, C.; Wang, H.; Lin, P.H.; Yao, Q.; Chen, C. Current advances in research and clinical applications of PLGAbased nanotechnology. Expert Rev. Mol. Diagn. 2009, 9, 325-341. [CrossRef]

45. Armarego, W.L.F.; Perrin, D.D. Purification of Laboratory Chemicals; Butterworth-Heinemann: Oxford, UK, 2000; ISBN 0750637617.

Sample Availability: Samples of the compounds are not available from the authors.

(C) 2020 by the authors. Licensee MDPI, Basel, Switzerland. This article is an open access article distributed under the terms and conditions of the Creative Commons Attribution (CC BY) license (http://creativecommons.org/licenses/by/4.0/). 